\title{
Geographic Concerns on Flood Climate and Flood Hydrology in Monsoon-Dominated Damodar River Basin, Eastern India
}

\author{
Sandipan Ghosh and Biswaranjan Mistri \\ Department of Geography, The University of Burdwan, Barddhaman, West Bengal 713104, India \\ Correspondence should be addressed to Sandipan Ghosh; sandipanghosh19@gmail.com
}

Received 12 August 2014; Revised 30 November 2014; Accepted 3 December 2014

Academic Editor: Achim A. Beylich

Copyright (C) 2015 S. Ghosh and B. Mistri. This is an open access article distributed under the Creative Commons Attribution License, which permits unrestricted use, distribution, and reproduction in any medium, provided the original work is properly cited.

In the Lower Gangetic Plain of West Bengal, the furious monsoon flood of Damodar River is a recurrent hydrometeorological phenomenon which is now intensified by the human activities. At present, the flood regulation system of Damodar Valley Corporation (DVC) is not capable of managing gigantic inflow water (which appeared as surface runoff and channel flow) coming from the wide fan-shaped upper catchment of Damodar River. As a result, the lower basin of Damodar (covering Barddhaman, Hooghly, and Howrah districts of West Bengal) annually experiences low to high magnitude of floods and overflow condition because the existing canal system, streams, palaeochannels, and Damodar River itself have lost their former carrying capacity to accommodate all excess water within its active domain due to over siltation and drainage congestion. So when the DVC dams are not able to regulate flood flow, then extreme rainfall of prolonged duration over the basin turns the normal situation into devastating flood, like the years of 1978 and 2000 in West Bengal. Identifying the existing problems of lower Damodar River, this paper principally tries to assess the potentiality of flood climate and to estimate the contributing rainfall-runoff, peak discharge, and existing carrying capacity of river in relation to increasing flood risk of lower basin using the quantitative hydrologic expressions.

\section{Introduction}

The flowing water finds the lowest parts of the earth's surface, forming small rivulets that merge into larger ones and eventually find their way into a river. When a river carries much more water than usual, it is said to be "in spate," a term of uncertain origin but which may be derived from the Dutch verb spuiten, meaning "to flood" [1]. A flood is an unusual high stage of a river due to runoff from rainfall and/or melting of snow in quantities too great to be confined in the normal water surface elevation of the river or stream, as the result of unusual meteorological combination [2]. "Flood" means that the flow in the river is in such an excess as to raise the level of the river at places so that it overflows the banks and rises to a level higher than the adjacent countrysides, thus inundating the areas adjacent to the channel $[3,4]$. The river fails at that time to transmit the excess flow keeping it within the confines of its bank heights. A flood thus comprises two main phases, namely, "the land phase" where rain rejected by soil becomes runoff and generates flood and "the channel phase" which follows the land phase closely and starts when surface runoff enters the stream channels. Ordinarily, when speaking of floods, we mean that the channel phase is the most spectacular and on the whole the most destructive [4]. The term "flood climate" is probably introduced by Hayden (1988) who has developed a global classification of flood-producing climates based on the mean seasonal state of the atmosphere [5]. Hirschboeck (1988) introduces the discipline of "flood hydroclimatology" which gives focus of hydrometeorological-scale atmosphere activity, while, at the same time, seeking to place this activity within a broader spatial and temporal climatic perspective of flood [6]. Tropical climates including monsoon climate have high potentiality of floods because, here, the atmosphere (i.e., primary reservoir of flood water) is primarily characterized by barotropy, typical of tropical low latitudes, precipitation is released by synoptic convective activity (e.g., tropical thunder storms), local convective activity (thunderstorms), and rising circumequatorial air at the Intertropical Convergence Zone (ITCZ). Flood hydrology deals with functionality of time- 
and space-dependent processes of waters and is focused on hydraulic and engineering dimensions of floods. Flood hydrology includes hydrometeorological aspects of flood, flood dynamics of channel, flood routing, and identification of flood stage, flood frequency analysis (i.e., design flood), flood risk estimation, and flood management $[2,7]$.

Nature has been kind to India in bestowing a season like monsoon (June-October) during which almost 75 to 80 percent of annual rainfall is received. Naturally, when almost the entire year's rainfall occurs in a period of few months, floods are bound to occur in its river [8]. Floods in relation to climate change and meteorological variability in recent past in India have already been analyzed and discussed by many researchers [8-17]. Large synoptic systems ranging in force from tropical lows to cyclones are the main cause of unusually large floods on the Indian rivers [18]. It is now found that the rainfall spreading over a short time may cause flood but the same spread over a longer span may result in a drought. There is considerable temporal variation in the monsoon rainfall related climatic variability in India. For example, 1917 and 1961 were excess monsoon years $(>1000 \mathrm{~m}$ or +18 percent) and 2002, 1987, 1972, 1918, 1899, and 1877 were major deficient monsoon years $(<700 \mathrm{~mm}$ or -18 percent $)$ [16]. Also, twentieth century development in tropical meteorology reveals that poor monsoon is found to be associated with warm El nino events. The global warming and short-term climate change of Indian subcontinent simultaneously and forcefully influence the monsoon system affecting spatial trend of rainfall and occurrences of extreme floods. On the basis of marine sediment cores and isotope dating in India, the monsoon intensity shows a steady increase from $\sim 1700 \mathrm{AD}$ to present [16]. Some recent studies [17, 19] have shown contrasting results of a decreasing trend in the frequency of tropical cyclones and monsoon depressions and significant rising trends in the frequency and magnitude of extreme rainfall events over India between 1951 and 2010. Wet extremes are projected to become more severe in many areas of India where mean precipitation is expected to increase and dry extremes are projected to become more intense in areas where mean precipitation is projected to decrease [17]. Now, it has been found that the rainfall in 6-hour and 3hour duration can be about 75 and 60 percent of the 24 hour rainfall in the Himalayan foothills and central plateaus and it is intense rainfall which gives rise to flash floods in the rivers [11]. The phenomena of Mumbai flood in July 2005, Uttarakhand flood disaster in June 2013, and, most recently, flood of Jammu and Kashmir in September 2014 is compelled to think about predicting flood dynamics, changing climatic pattern, and improvement of flood forecasting. The flood generating rainstorms are usually of 3-day duration and are confined in the whole Ganga Basin where the Damodar River Basin is a subcatchment of it [12]. Entire Damodar River Basin is situated in the high-moderate flash flood zone (80 to $120 \mathrm{~mm} 3$ hour rainfall). So, observing the flood potentiality of this basin, it is selected as a research area to assess the temporal trend of flood climate and flood hydrology. In this regard, when we consider the floodplains of West Bengal, the flood is regarded as extreme hydrometeorological annual phenomenon of monsoon season when the excessive surface runoff and over flow of alluvial rivers submerge the surrounding low lying areas of Barddhaman, Hooghly, and Howrah districts. At that time, the surface drainage systems of lower Damodar Basin failed to cope up with it. That is the main concern of inhabitants of southern West Bengal.

The flood history of Damodar River is very much popular to West Bengal, as well as India, because this River is identified as "Sorrow of Bengal" due to havoc destruction in annual floods, particularly in the lower reach [20]. If we consider floods as extreme hydrological phenomenon and as quasidynamic equilibrium fluvial process, then it is not surprising to us that, to attain the present form of lower Damodar Floodplain, the flood aggradation and degradation are considered as the prime processes. But, in reality, settlements beside a river, like Damodar River, can be a mixed blessing; for once in a while, the river may overflow its banks and generate a heavy toll of property losses, income losses, and sometimes losses of life as well. In some cases, man has learned to live with such periodic inundations of the fertile floodplain [21]. The causes of floods can be natural, but human interference intensifies many floods. The decision to live in a floodplain, for a variety of perceived benefits, is one that is fraught with difficulties. The increase in flood damage is related to the increasing number of people living in floodplain regions [22]. Remembering and analyzing the past flood events of lower Damodar River, the very common but unsolved problem of Damodar River Basin is to manage the huge inflow water of runoff from upper catchment through the existing engineering structures of Damodar Valley Corporation (DVC) flood regulation system. It is a ground reality that incapable flood storage system, low canal consumption, declining carrying capacity of river, decayed palaeochannels, mounting unscientific embankments, and so forth are found to be the chief causes of recent floods and these are not capable of coping up with huge volume of runoff. The essential part of this study is the precise estimation and forecasting of runoff in relation to flood climate and flood risk of lower Damodar River. On the basis of hydrogeomorphic perspective of flood, we have considered the following five prime objectives of study:

(1) understanding the geohydrological set-up of Damodar River Basin,

(2) analyzing the influence of monsoon rainfall on flood risk,

(3) estimating potential runoff to understand the magnitude of flood discharge,

(4) quantifying the potential carrying capacity of Damodar River and current threshold level of bankfull discharge,

(5) identifying the dominant key factors of flood risk in the lower part of Damodar River Basin.

\section{Previous Works on Damodar Floods}

Floods, a popular theme of research as far as the monsoondominated rivers (namely, Narmada, Tapti, Kosi, Ganga, Kaveri, Godabari, Krishna, Brahmaputra, Luni, Pennar, Ajay, 
and Damodar) of India are concerned, are investigated with the perspectives of flood hydrology, flood geomorphology, palaeohydrology, and hydrometeorology. Large floods of Indian rivers basins and their temporal variations have been studied by many researchers $[8,12,13,15,23-32]$. In West Bengal, the lower segment of Damodar River is taken as main spatial unit of study by many researchers and scholars of different disciplines to analyze the flood ferocity and propensity. The flood history of Damodar during the period 1817-1917 can be traced from the Glass [33] report submitted to the then Bengal government as observed at Raniganj, West Bengal [21, 33, 34]. The pre-dam and post-dam temporal character of floods and results of dam construction are well analyzed by many workers [33, 35-42]. The causes, factors, extent, and trend of floods and phases of changing courses of Damodar River are studied, investigated, and assessed minutely by few Indian geographers and geologists [21, 34, $43,44]$.

\section{Methodology}

Uncertainty of physical event is very much allied with high monsoon rainfall, runoff generation, and flash floods [46] but if we estimate the current status of flood flow or bankfull discharge or water accommodation capacity of channel reach, then an idea of emergent flood risk can be found with some quantitative judgments. The long continuous, up-to-date, and reliable rainfall data, hydrological records, and geomorphic data are an indispensable part in the study of changing flood climate, fluvial dynamics, and flood risk assessment. Following fluvial hydrologic approach, the drainage basin is selected as the main spatial unit of study. Total workflow of methodology is confined within selection of research problem, study area choice, data collection, data processing through Geographic Information System (GIS) and statistical software, data analysis through quantitative judgments and thematic maps, and finally data interpretation including significance of this study.

3.1. Data Collection. The study about floods always incorporates an interdisciplinary approach of earth science which includes the method and techniques of hydrology, hydroclimatology, and fluvial geomorphology. We have collected secondary data and information mostly from Damodar Planning Atlas [45], book entitled "Lower Damodar River, India: Understanding the Human Role in Changing Fluvial Environment" [21], websites of Irrigation and Waterways Department of West Bengal, West Bengal State Marketing Board, Indian Meteorological Department of India, Geological Survey of India, Google Earth, and different research articles relating to Damodar River. We have also employed the maps of National Atlas Thematic Mapping Organization (NATMO), Survey of India (SOI) toposheets ( $73 \mathrm{M} / 7, \mathrm{M} / 11, \mathrm{M} / 12, \mathrm{M} / 15, \mathrm{M} / 16$, $\mathrm{N} / 13$, and $79 \mathrm{~A} / 4$ ) and Geological Survey of India (GSI). To get elevation data, we have collected ASTER (Advanced Spaceborne Thermal Emission and Reflection Radiometer) data (2013) from the website of United State Geological Survey.
3.2. Data Analysis. MapInfo Professional 9.0 and ESRI ArcGis 9.2 GIS software are used to represent spatial data into organized format and thematic maps. The delimitation and subsetting of study area (i.e., Damodar River Basin) is completed with the help of Leica Erdas 9.1 imagine software using the topographical sheets (projected in UTM WGS 84 projection). After collecting secondary data, we have employed few statistical analyses, namely, mean, standard deviation, skewness, correlation, regression, probability distribution, and $t$ - and chi square test, for the hydrological interpretation of stream flow data in Microsoft Excel 2007 and SPSS 14.0. Finally, gathering the results, we have made significance of adopted methods, interpretation of outcomes, and conclusion to chalk out the major findings of this analysis.

3.3. Quantitative Hydrologic Techniques. To derive significant information and to assess the trend of Damodar floods, few quantitative techniques of fluvial hydrology are used here. The employed quantitative expressions are summarized as follows.

3.3.1. Runoff Volume Estimation. To measure the annual runoff volume of Damodar River at Rhondia (West Bengal), Dhir et al. (1958) had developed an empirical equation [48]. Consider

$$
\begin{aligned}
& \text { Annual Runoff Volume (in million } \mathrm{m}^{3} \text { ) } \\
& \text { = } 13400 \text { Annual Precipitation (in } \mathrm{cm} \text { ) }-5.7510^{5} \text {. }
\end{aligned}
$$

3.3.2. Runoff-Rainfall Relation. Employing linear regression and $t$-test, we have established a significant rainfall-runoff equation to predict the trend of runoff on the basis of actual rainfall and runoff data (1934-1950) at Rhondia. The equation is expressed as follows:

$$
\text { Runoff }(Y)=0.819 \text { Rainfall }(X)-530.21 \text {. }
$$

3.3.3. Potential Runoff Estimation. Converting annual peak discharge $\left(\mathrm{m}^{3} \mathrm{~s}^{-1}\right)$ of Damodar to one $-\mathrm{m}^{3} \mathrm{~s}^{-1}$ day in $\mathrm{m}^{3}$ (i.e., maximum volume of water flow passing through the measuring station) and dividing it by drainage area $\left(\mathrm{km}^{2}\right)$ above Rhondia, we have obtained potential contributing runoff $(\mathrm{mm})$ after satisfying the storage of dams. The expression is as follows [7]:

$$
\begin{aligned}
& \text { Potential Contributing Runoff } \\
& \qquad=\frac{(86400 \text { Peak Discharge }) 10^{4}}{\text { Drainage Area } 10^{6}} .
\end{aligned}
$$

3.3.4. Gumbel Flood Frequency. Flood frequency analysis is a widely used technique to derive flood discharge with certain return period. According to Gumbel probability distribution (GPD) the exceedance probability $(P)$ is given by $[7,49]$

$$
P=1-e^{-e-y},
$$


where $y$ is called reduced variates given by

$$
y=\left[\left(X-X_{\text {mean }}\right)+\frac{0.45 \sigma}{0.7797 \sigma}\right],
$$

where $X_{\text {mean }}$ is the mean of sample, $X$ is the observed data, and $\sigma$ is standard deviation of sample.

If $X_{T}$ denotes the magnitude of the flood with return period of $T$ years $\left[T=1 /\left(1-e^{-e-y}\right)\right]$,

$$
X_{T}=X_{\text {mean }}+K_{T} \cdot \sigma,
$$

where $K_{T}$ is the frequency factor $\left(y_{T}-y_{\text {mean }} / \sigma_{n}\right), y_{T}$ is the reduced variate, $y_{\text {mean }}$ is the mean of reduced variate, and $\sigma_{n}$ is standard deviation of reduced variates (calculating these from table value of Gumbel distribution). In this case, we have used annual peak flow data of Damodar River (measured at Anderson Weir, Rhondia) - (1) pre-dam phase (1933-57) and (2) post-dam phase (1958-2007).

3.3.5. Carrying Capacity and Threshold Discharge. To estimate potential carrying capacity $\left(\mathrm{m}^{3}\right)$ of a particular reach and threshold level of flood discharge $\left(\mathrm{m}^{3} / \mathrm{s}\right)$, we have calculated mean cross-sectional area $\left(\mathrm{m}^{2}\right)$ and mean maximum length of the reach $(\mathrm{m})$ of three selected channel sections of Damodar, namely, (1) Rhondia to Jujuti reach, (2) Jujuti to Chanchai reach, and (3) Chanchai to Paikpara reach, using ASTER data and Global Mapper 13.0 software. The developed equations are as follows [7]:

$$
\begin{aligned}
& \text { Carrying Capacity of Reach } \\
& =\text { Mean Cross - Sectional Area } \\
& \quad * \text { Mean Maximum Length of Reach, }
\end{aligned}
$$

Threshold Discharge or Bankfull Discharge

$$
=\frac{\text { Carrying Capacity of Reach }}{86400} \text {. }
$$

\section{Geographical Outline of Study Area}

The Damodar River, or the Deonad Nadi as it is known in its upstream sector, is a subsystem of the Ganges River system of India. The local meaning of the word Damodar is fire in "womb" or Udar, which is "full of fire." This implies that the Damodar flows through a coal-rich area of Gondwana Formation. The river rises in the Chotanagpur Plateau approximately at $23^{\circ} 37^{\prime} \mathrm{N}$ and $84^{\circ} 41^{\prime} \mathrm{E}$ [21]. The main tributaries are the Barakar, Tilaiya, and Konar. Below the confluence of the Barakar and Damodar, there are a few insignificant tributaries such as the Nunia and Sali. Once the main distributaries were the Khari, Banka, Behula, and Gangur, but now they look more like independent rivers. Near Palla, the River takes a sharp southerly bend. Below Jamalpur, the river bifurcates into the Kanki-Mundeswari and the Amta Channel-Damodar and joins the Hooghly River (also spelled Hugli) at Falta some $48.3 \mathrm{~km}$ south of Kolkata [21]. The Damodar River Basin is a subbasin and part of the Ganges River spreading over an area of about
$23,370 \mathrm{~km}^{2}$ in the states of Jharkhand and West Bengal. The sample study area (Figure 1) includes the lower reach of Damodar River in between Rhondia (Galsi I Block) and Paikpara (Jamalpur Block). Its latitudinal extension ranges from $23^{\circ} 00^{\prime}$ to $23^{\circ} 22^{\prime} 10^{\prime \prime} \mathrm{N}$ and longitudinal extension ranges from $87^{\circ} 28^{\prime} 23^{\prime \prime}$ to $88^{\circ} 01^{\prime} 00^{\prime \prime} \mathrm{E}$. At Anderson Weir (near Rhondia Village) the estimated basin area coverage of Damodar River is $19,920 \mathrm{~km}^{2}$. The total stretch of Damodar between Rhondia and Paikpara is approximately $82 \mathrm{~km}$. This reach crosses Sonamukhi and Patrasayer blocks (Bankura), Kanksa, Galsi I, Galsi II, Barddhaman I, Khandaghosh, Rayna, Memari I, and Jamalpur blocks (Barddhaman). The slope category for 5-30 metres of relief of lower Damodar Valley is flat lands of $0^{\circ}-$ $0^{\circ} 30^{\prime}$, having $7.74 \%$ of Basin area and slope category for upper $30-60$ metres of relief is gentle sloping plain of $0^{\circ} 30^{\prime}-1^{\circ} 00^{\prime}$, having $3.57 \%$ of Basin area [50]. Sixteen large magnitudes floods occurred in its basin during 1823-1943, though, after constructions of dams and reservoirs, the ferocity of flood has been reduced but the number of floods has been increased [44]. The floods of 1823, 1840, 1913, 1935, 1941, 1958, 1959, and 1978 had peaks of more than $16,992 \mathrm{~m}^{3} \mathrm{~s}^{-1}$. A peak flow of about $18,678 \mathrm{~m}^{3} \mathrm{~s}^{-1}$ has been recorded three times: August 1913 and 1935 and October 1941 [21]. To mitigate flood, the Damodar Valley Corporation (DVC) came into existence on July 7, 1948, by an act of the constituent assembly [42]. In the first phase, only four dams, namely, Tilaiya (1953), Konar (1955), Maithon (1957), and Panchet (1959), were constructed by DVC. Then one more reservoir, Tenughat (1978) on the upper Damodar River (under the control of Jharkahnd Government) and one barrage, Durgapur Barrage (1955) on the middle Damodar River (under the control of West Bengal Government) are constructed sequentially [42].

\section{Results and Discussion}

5.1. Influence of Monsoonal Rainfall on Flood Propensity of Damodar River. The flow of any stream is determined by two entirely different sets of factors, the one depending upon the climate with special reference to the precipitation and the other depending upon the physical characteristics of the drainage basin. Rivers do not, however, remain at a high stage throughout the monsoon season. It is only after a spell of heavy rains, which may last for a period of several days, that large volume of runoff is generated in the catchments and the rivers experience floods annually [12]. Analysis of oneday extreme rainfall series shows that the intensity of extreme rainfall has increased over Orissa and West Bengal. The flood risk was more in the decades of 1981-1990, 1971-1980, and 1991-2000 [17]. The degree of flood risk has increased during the last two decades mostly over the eastern coast and West Bengal [17].

Monsoon depressions are the important synoptic systems that cause floods in the Peninsular Rivers, during the southwest monsoon season (June-October). On average, six depressions are mostly formed in the vicinity of Bay of Bengal during the three months of July to September [51]. These disturbances generally move west-north-westwards along 


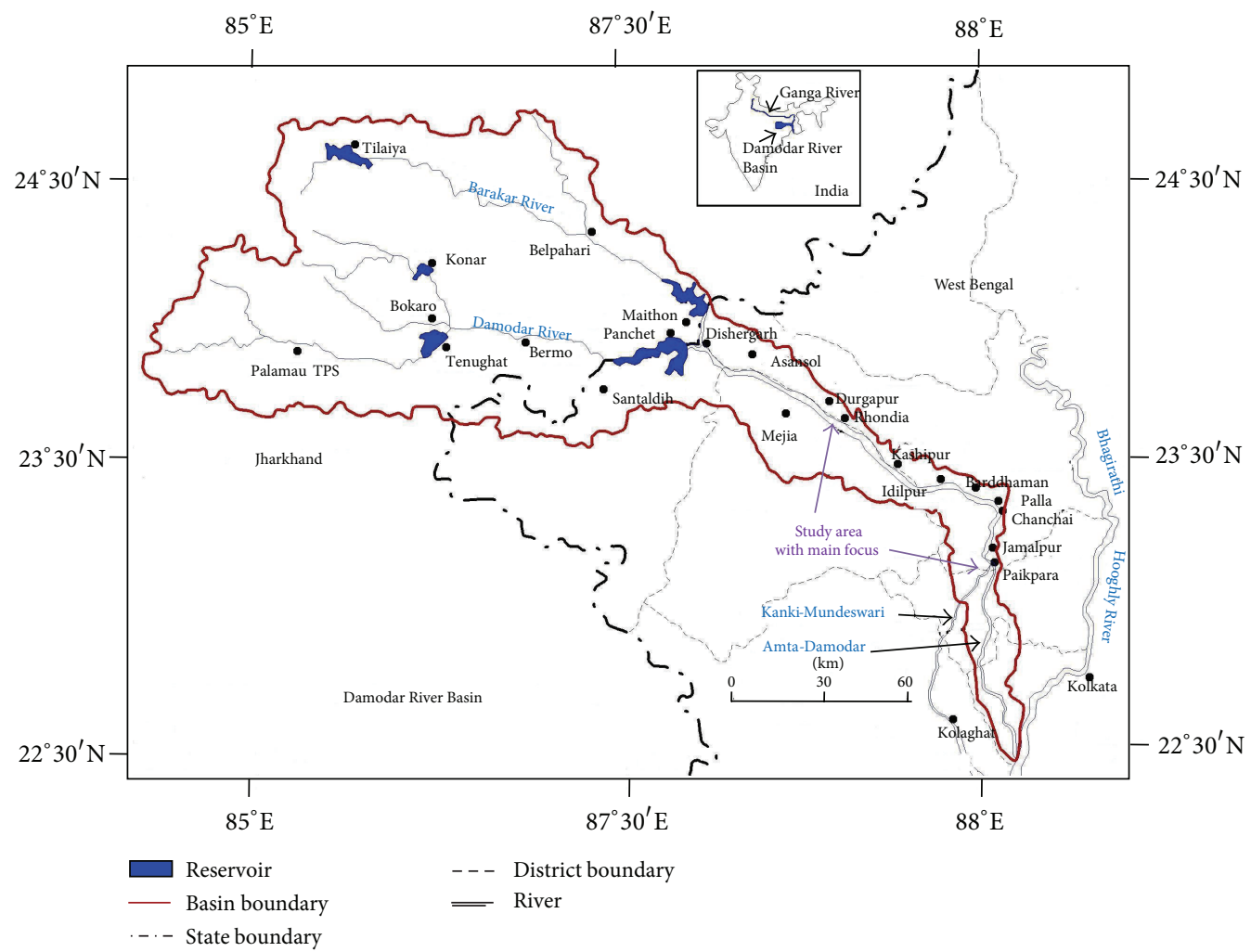

(a)

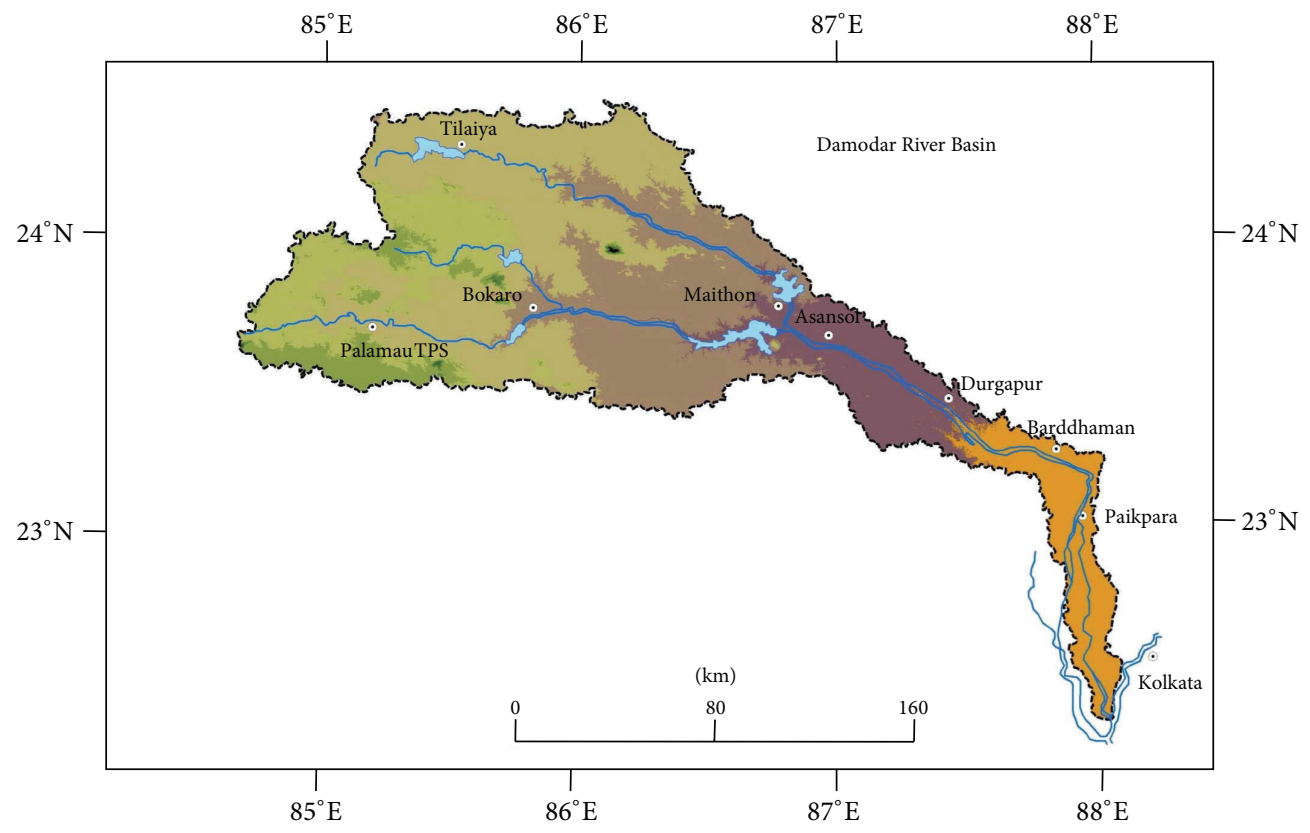

ASTER DEM elevation (m)

$\begin{array}{llll}\square-50 & 600-750 & & \\ 0 & \text { Important location } \\ 50-150 & 750-900 & \square & \text { Reservoirs } \\ 150-300 & 900-1050 & \square-- & \text { Basin boundary } \\ 500-450 & \square 1050 & \square & \text { River } \\ 450-600 & & \end{array}$

(b)

FIGURE 1: (a) Spatial extent of Damodar River Basin and (b) ASTER elevation map of the basin. 
the Lower Gangetic Plain to Chotanagpur Plateau after their formation at the head of the Bay of Bengal $[37,51]$. The tracks of depressions are following the lower segment to upper catchment of Damodar River Basin. It is well know that heavy rainfall occurs in the southwestern sector of the monsoon depression due to strong convergence in that sector [51]. It has been found that the high flash-flood magnitudes of 195057 and 1958-69 are associated with 118 and 217 numbers of cyclones (which includes cyclonic disturbances: wind speed 17 knots or more, cyclones: 34 knots of more, and severe cyclones: 48 knots or more) of Bay of Bengal, respectively, but low flood magnitude of 1988-95 is related to only 95 numbers of cyclones [21].

Lower segment of the basin is affected by the floods due to upstream heavy rainfall and huge runoff volume generated in the upper catchment (i.e., western part of Maithon and Panchet dams) which consists of two drainage systems: (a) Damodar drainage system and (b) Barakar drainage system. It is estimated that Damodar catchment receives monsoon rainfall (June-October) of 855.57-1043.55 mm and Barakar catchment receives monsoon rainfall of 840.54$1079.81 \mathrm{~mm}$ annually [52]. At present, significant interannual and intraseasonal variabilities in the observed monsoon rainfall are displayed over this so-called sub-humid region, resulting in recurrent droughts and floods [53]. It is projected that 10-15 percent of rainfall will increase in area of average monsoon rainfall over the Indian subcontinent but the date of onset of summer monsoon over central India could become more variable in future. More intense rainfall spells are also projected in a warmer atmosphere, increasing the probability of extreme rainfall events and flash-floods in the sun-mountainous or plateau scarp region $[11,53]$.

The main hydroclimatic factors which influence runoff and flood of Damodar can be categorized as follows [54]: (1) type of rainfall, (2) rainfall intensity, (3) duration of rainfall on basin (intense short period or prolong duration), (4) direction of storm, depression and cyclone movement, and (5) antecedent rainfall and soil moisture. Heavy incessant and prolonged rainfall for long period is the basic cause of floods because enormous amount of water gets collected on the surface flowing as runoff. Higher magnitude of rainfall coupled with a larger catchment area, like Damodar Basin $\left(23,370 \mathrm{~km}^{2}\right)$, leads to a greater volume of runoff. We have emphasized on the following influences of monsoonal rainfall and catchment characteristics on flood risk of lower Damodar Basin.

(1) More or less same monsoonal rainfall pattern is observed both in the districts of upper catchment and lower catchment (Table 1). Within the Damodar Command Area of DVC, the upper and middle parts of Basin receive $1,209 \mathrm{~mm}$ rainfall annually and lower parts of Basin receive $1,329 \mathrm{~mm}$ [42]. Therefore, large fan-shaped contributing area of Damodar annually receives huge rainfall and due to low infiltration capacity and high runoff coefficient of rockydeforested upper catchment, 70 to 80 percent of rainfall converted into surface runoff. Due to high drainage density of upper catchment, huge volume
TABLE 1: Subdivisional monsoonal rainfall covering the Damodar River Basin.

\begin{tabular}{lcc}
\hline Year & $\begin{array}{c}\text { Rainfall }(\mathrm{mm}) \text { in } \\
\text { Jharkhand subdivision }\end{array}$ & $\begin{array}{c}\text { Rainfall (mm) in } \\
\text { Gangetic West Bengal } \\
\text { subdivision }\end{array}$ \\
\hline 2005 & 1105.0 & 1136.0 \\
2006 & 1092.0 & 1126.0 \\
2007 & 1093.0 & 1127.0 \\
2008 & 1092.5 & 1291.7 \\
2009 & 1002.6 & 971.5 \\
2010 & 1084.5 & 1140.6 \\
2011 & 1101.5 & 1394.7 \\
$1951-2000$ & 1091.9 & 1167.9 \\
(mean normal & & \\
rainfall) & & \\
\hline
\end{tabular}

Source: IMD, http://www.imd.gov.in/, retrieved on December 26, 2011.

of runoff appears as excessive stream flow which finally contributes to the main Damodar River, below Panchet and Maithon Dams.

(2) Rains of long duration and direction of monsoonal depressions (generally south to north-west from Gangetic West Bengal) annually aggravates huge volume of inflow water into the reservoirs of DVC. During late monsoon, the reservoirs including the rivers remain bankfull and groundwater of alluvial West Bengal is recharged to the fullest extent. A sudden cloudburst or strong depressional rainfall at this juncture frequently causes a disastrous flood. The month of September-early October is now considered as cruelest one for lower Damodar River, because all the major floods of 1956, 1958, 1959, 1978, 1995, and 2000 appeared in this session (Table 2).

(3) The eastern parts of Jharkhand and Gangetic West Bengal are recommended as the one of major rainstorm zones and flood prone areas of India [12, 13]. It has been found that, on an average of 25 years, the average monsoonal rainfall in 6 hours ranges between 14 and $16 \mathrm{~cm}$ in the parts of eastern Jharkhand and western West Bengal [37, 39].

(4) When Jharkhand Division (73.70 percent share in the basin) experiences intense rainfall of wide coverage, at that time, Gangetic West Bengal (26.30 percent share in the basin) is already oversaturated by continuing monsoonal depressions and lower catchment receives more than $1400 \mathrm{~mm}$ rainfall (Figure 2). Then, uncontrolled inflow runoff of upper catchment (released at last by Durgapur Barrage) integrates with further additional rainfall of Gangetic West Bengal and enormous volume of water passes through congested, silted, and oversaturated lower Damodar River (Figure 2) which is further narrowing down next to downstream of Barddhaman town. So, the overflow of river and additional runoff of lower catchment turns the inundated situation into misery. 
TABLE 2: Rainfall recorded during monsoonal major foods in the Damodar Valley (DV) and Barddhaman District (BD).

\begin{tabular}{lccc}
\hline Year & Month & Date & $\begin{array}{c}\text { Total storm } \\
\text { rainfall }(\mathrm{mm})\end{array}$ \\
\hline $1913(\mathrm{DV})$ & August & 5 to 11 & 314 \\
$1935(\mathrm{DV})$ & August & 10 to 15 & 288 \\
$1958(\mathrm{DV})$ & September & 14 to 16 & 166 \\
$1959(\mathrm{DV})$ & September- & September 30 to & 231 \\
$1978(\mathrm{DV})$ & October & October 7 & 184 \\
$1995(\mathrm{BD})$ & September & 26 to 29 & 369 \\
$2000(\mathrm{BD})$ & September & 26 to 28 & 800 \\
\hline
\end{tabular}

Source: $[21,47]$.

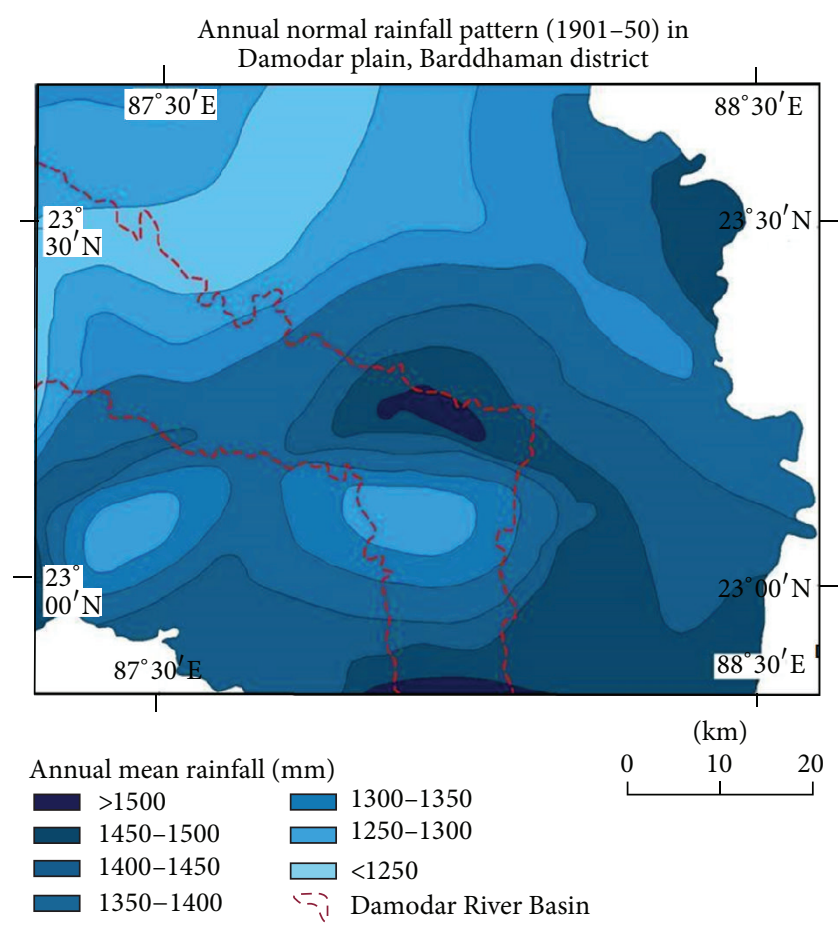

Figure 2: Spatial distribution of mean annual rainfall in lower segment of Damodar River Basin. Source: Chatterjee [45].

5.2. Estimating Surface Runoff and Flood Risk. Flood risk estimation includes the task of evaluating the probability of a flood arriving which is greater than that which can be safely accommodated [55]. Usually, the risk is expressed as the probability of such an occurrence or phenomenon within the intended design life of a scheme [55] or the risk involves quantification of the probability that a hazard (e.g., flood) will be harmful and the tolerable degree of risk depends upon what is being risked [46]. The uncertainty of event is very much allied with high monsoon rainfall, runoff generation, and flash floods but if we estimate the current status of flood discharge or runoff volume, then an idea of emergent flood risk can be found with some quantitative judgment.

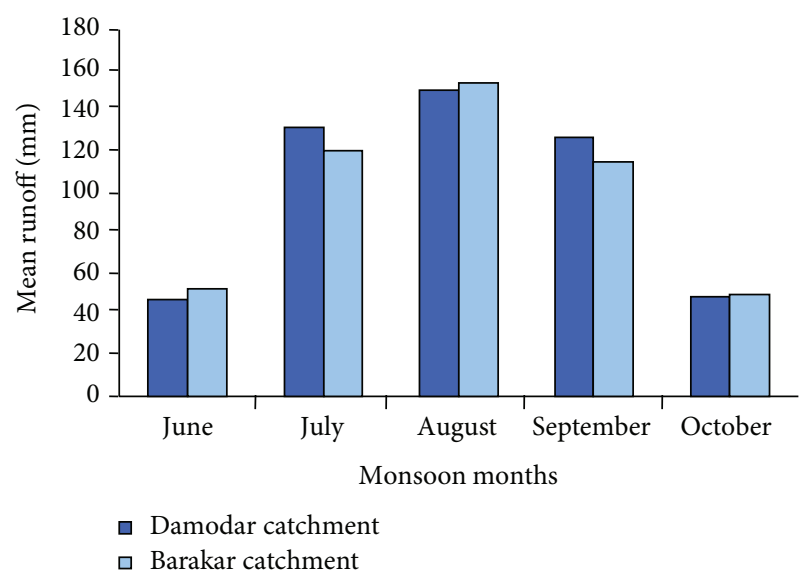

FIGURE 3: Estimated mean monsoon (June to October) runoff in the catchments of Damodar and Barakar.

Runoff is a portion of part of the hydrological cycle connecting precipitation and channel flow. The basin hydrological cycle can be viewed simply as inputs of precipitation being distributed through a number of storages by a series of transfers, leading to outputs of basin channel runoff, evapotranspiration, and deep outflow of ground water [56]. The watershed or catchment is the area of land draining into a stream at a given location [1]. To describe the surface water yield of basin (after soil moisture storage), the estimation of surface runoff obtained prime importance. It plays dual role in basin hydrogeomorphology-(1) fluvial erosional agent and gross sediment yield and (2) accumulation of all water and final discharge to main channel [13].

It is calculated that Damodar catchment yields monsoon runoff (June-October) of 385.17-560.71 mm and Barakar catchment yields monsoon runoff of $416.59-565.84 \mathrm{~mm}$ annually (Figure 3) [52]. For estimation of runoff yield of Damodar Basin at Anderson Weir (Rhondia, West Bengal), Dhir et al. [48] had developed an empirical equation on the basis of a range of rainfall-runoff and stream flow data. Actually, they developed numerous individual equations for Kangsabati (West Bengal), Tapti (Gujrat), Chambal (Rajasthan), Tawa (Madhya Pradesh), Ghataprabha (Andhra Pradesh), and so forth river basins of India. These equations are well used by Central Water Commission (Government of India) and International Water Management Institute for ungauged sites of Indian catchments. It has been assumed that, from Rhondia, the remaining upper catchment of $19,920 \mathrm{~km}^{2}$ has contained a considerable portion of rainfalls and produced runoff into the main channel, though it varies from region to region on the basis of land use, land cover, geology, soil, rainfall intensity, and so forth. At Rhondia, for the upper catchment area $\left(19,920 \mathrm{~km}^{2}\right)$ of Damodar River, a direct rainfall-runoff equation is developed to estimate potential runoff volume at upper catchment [30].

From the above analysis (Table 3), we can say that annual runoff yield of Damodar Basin is much greater, ranging from 16961580 million $\mathrm{m}^{3}$ (Barhi) to 19900200 million $\mathrm{m}^{3}$ (Burdwan), for the decade of 1901-50. It is easily seen that 
TABLE 3: Calculated runoff of Damodar Basin from annual normal rainfall data (1901-50) of selected stations.

\begin{tabular}{lcccc}
\hline Stations & ${ }^{1}$ Mean annual rainfall $(\mathrm{mm})$ & $\begin{array}{c}\text { Annual runoff volume } \\
\left(\text { million } \mathrm{m}^{3}\right)\end{array}$ & $\begin{array}{c}\text { Annual depth of runoff } \\
(\mathrm{mm})\end{array}$ & Runoff/rainfall ratio \\
\hline Barhi & 1308.7 & 16961580 & 852.34 & 0.651 \\
Hazaribagh & 1338.7 & 17363580 & 872.54 & 0.651 \\
Ramgarh & 1306.0 & 16925400 & 850.52 & 0.651 \\
Jamtara & 1376.7 & 17872780 & 898.13 & 0.652 \\
Dhanbad & 1309.0 & 16965600 & 852.54 & 0.651 \\
Barjora & 1469.0 & 19109600 & 967.84 & 0.658 \\
Sonamukhi & 1204.0 & 15558600 & 863.25 & 0.717 \\
Asansol & 1324.9 & 17178660 & 960.28 & 0.725 \\
Mankar & 1209.6 & 15633640 & 785.61 & 0.649 \\
Burdwan & 1528.0 & 19900200 & 999.00 & 0.653 \\
Standard deviation & 101.16 & 1355498 & 68.65 & 0.023 \\
Mean & 1337.46 & 17346964 & 871.71 & 0.665 \\
Skewness & 0.63 & 0.63 & 0.37 & 1.770 \\
\hline Dass & & &
\end{tabular}

Data source: ${ }^{1}[45]$.

the potentiality of runoff generation is more or less the same in the upper catchment area of Damodar $(850-900 \mathrm{~mm}$ per year). Based on mean annual Basin rainfall of $1337.46 \mathrm{~mm}$, we have been calculated potentially mean annual basin runoff of $871.71 \mathrm{~mm}$ which is generated, having positively skewed distribution. After getting idea of past condition, we have employed the recent districtwise monsoonal rainfall data (2006-10) which is regularly provided by website of Indian Meteorological Department (IMD, Pune). In between June and September, rainfall, soil moisture, and runoff reach up to maximum levels which contributed to greatest flood flows of lower Damodar Basin It have been found. Hazaribagh, Bokaro, and Dhanbad districts yield approximate mean runoff of 661, 640, and $669 \mathrm{~mm}$, respectively, in monsoon (2006-10). This runoff of upper catchment reaches downstream of Burdwan Plain through the main channel and it is further cumulated with the monsoonal runoff of Burdwan and Bankura districts which are 758 and $756 \mathrm{~mm}$, respectively, for 2006-10 (Figure 3). The important thing is that the basin area is reduced at downstream and mean annual runoff volume of 13882046 million $\mathrm{m}^{3}$ passes through this narrow channel. It aggravates the risk of inundation and flood in the lower portion of Damodar Basin in late Monsoon.

The above analysis (Table 4 and Figure 4) provides us with only a generalized idea about potentiality of runoff to be generated in the periods of 1901-1950 and 2006-2010. We have now established a linear regression equation dealing with seventeen years of estimated actual rainfall and runoff data (1934-1950) at Rhondia and a statistical significant test is employed to make that equation reliable and applicable to Damodar Basin. Here, we have assumed that the calculated runoff is generated within the basin area depending on the land use, land cover conditions, soil moisture, channel storage, rainfall intensity, evapotranspiration, and geological character of surface. So this rainfall-runoff relation reflects the hydrogeomorphic characteristics of Damodar Basin and

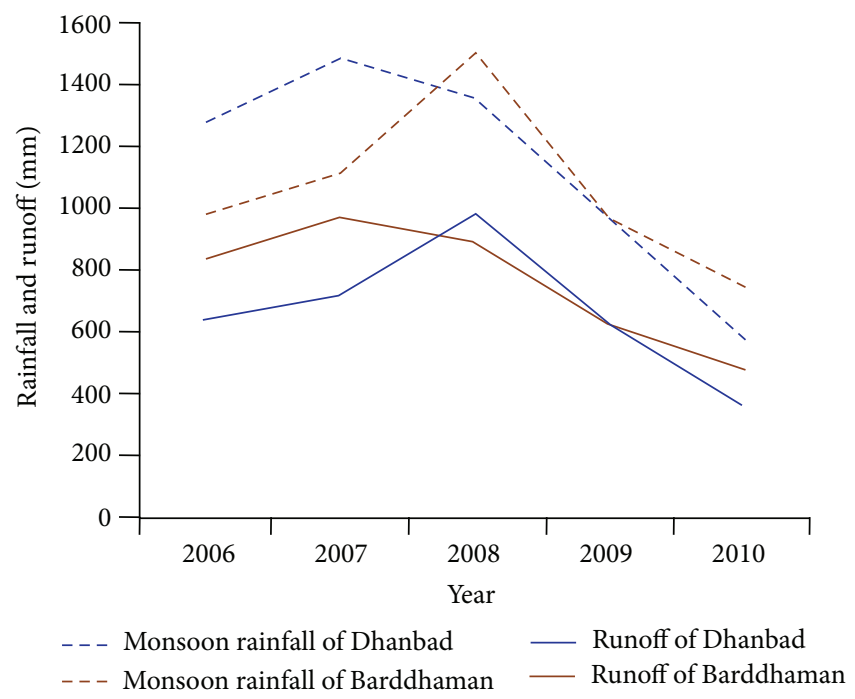

Figure 4: Monsoonal rainfall and runoff contrast (2006-10) of Dhanbad and Barddhaman districts.

flood risk of downstream region in particular. Again, establishing this significant regression equation, we can predict potential runoff depth of uncalculated years which will forecast the flood flow at Rhondia.

Observing the above calculations (Table 5) and two graphs (Figure 5), we have been able to establish a meaningful rainfall-runoff relation of Damodar Basin at Rhondia. From " $t$-test" of $b$ value and $r$ value, we have obtained that both slope of positive increasing trend line and correlation between rainfall and runoff are very much significant, rejecting the null hypothesis. Also, the distribution is positively skewed (0.63). With the fluctuation of rainfall, the runoff was also deviated but from 1934 to 1950, the runoff has an increasing positive annual trend $(Y=0.8194 X-530.21)$. On 
TABLE 4: Districtwise monsoonal rainfall-runoff estimation (2006-10) for Damodar River Basin.

(a) ${ }^{*}$ Monsoonal rainfall in $\mathrm{mm}$

\begin{tabular}{lccccc}
\hline District & 2006 & 2007 & 2008 & 2009 & 2010 \\
\hline Hazaribagh & 977.3 & 1113.5 & 1498.5 & 965.2 & 576.1 \\
Bokaro & 938.9 & 1027.1 & 1184.8 & 945.9 & 871.3 \\
Dhanbad & 1079.7 & 1488.4 & 977.8 & 896.0 & 748.9 \\
Burdwan & 1280.1 & 1483.0 & 1361.8 & 977.0 & 745.9 \\
Bankura & 1201.9 & 1555.2 & 1371.6 & 1001.7 & 704.5 \\
\hline
\end{tabular}

(b) Monsoonal runoff volume in million $\mathrm{m}^{3}$

\begin{tabular}{lccccc}
\hline District & 2006 & 2007 & 2008 & 2009 & 2010 \\
\hline Hazaribagh & 12520820 & 14345900 & 19504900 & 12358680 & 7144740 \\
Bokaro & 12006260 & 13188140 & 15301320 & 12100060 & 11100420 \\
Dhanbad & 13892980 & 19369560 & 12527520 & 11431400 & 9460260 \\
Burdwan & 16578340 & 19297200 & 17673120 & 12516800 & 9420060 \\
Bankura & 15530460 & 20264680 & 17804440 & 12847780 & 8865300 \\
\hline
\end{tabular}

(c) Predicted runoff depth in $\mathrm{mm}$

\begin{tabular}{lccccc}
\hline District & 2006 & 2007 & 2008 & 2009 & 2010 \\
\hline Hazaribagh & 628.55 & 720.17 & 979.16 & 620.41 & 358.67 \\
Bokaro & 602.72 & 662.05 & 768.13 & 607.43 & 557.25 \\
Dhanbad & 697.44 & 972.36 & 628.89 & 573.86 & 474.91 \\
Burdwan & 832.24 & 968.73 & 887.20 & 628.35 & 472.89 \\
Bankura & 779.64 & 1017.30 & 893.79 & 644.96 & 445.04 \\
\hline
\end{tabular}

Data source: * IMD, http://www.imd.gov.in/, retrieved on December 26, 2011.

TABLE 5: Establishing annual rainfall-runoff relation for Damodar River Basin at Rhondia (1934-50).

\begin{tabular}{lccl}
\hline Year & $\begin{array}{c}{ }^{1} \text { Mean annual } \\
\text { rainfall }(\mathrm{mm})\end{array}$ & $\begin{array}{c}{ }^{2} \text { Mean annual } \\
\text { runoff }(\mathrm{mm})\end{array}$ & Calculations \\
\hline 1934 & 1088 & 274 & $a=530.21$ \\
1935 & 1113 & 320 & $b=0.819$ \\
1936 & 1512 & 543 & Runoff $(Y)=\mathbf{0 . 8 1 9}$ rainfall $(X)-\mathbf{5 3 0 . 2 1}$ \\
1937 & 1343 & 352 & Coefficient of determination $\left(R^{2}\right)=\mathbf{0 . 6 3}$ \\
1938 & 1103 & 617 & \\
1939 & 1490 & 328 & Standard deviation of $Y=158$ mm \\
1940 & 1100 & 582 & Standard error of estimate of $Y=96$ mm \\
1941 & 1433 & 763 & Calculated $t$ value of $b=3.25$ \\
1942 & 1475 & 558 & Tabulated $t$ value $(0.01 \%$ confidence $)=2.95$ \\
1943 & 1380 & 492 & Degree of freedom $(\mathrm{df})=(n-2)=15$ \\
1944 & 1178 & 478 & Product moment correlation coefficient $(r)=\mathbf{0 . 7 9 4}$ \\
1945 & 1223 & 783 & Calculated $t$ value of $r=4.01$ \\
1946 & 1440 & 551 & Tabulated $t$ value $(0.01 \%$ confidence $)=2.95$ \\
1947 & 1165 & 565 & Null hypothesis is rejected and the equation is very much significant \\
1948 & 1271 & 720 & \\
1949 & 1443 & 730 & \\
1950 & 1340 & & \\
\hline
\end{tabular}

Data source: ${ }^{1,2}[2]$. 
TABLE 6: Normal monsoonal rainfall and calculated runoff amounts of selected districts (1951-2003).

\begin{tabular}{|c|c|c|c|c|c|c|}
\hline \multirow{2}{*}{ Districts } & \multicolumn{4}{|c|}{${ }^{1}$ Normal rainfall in $\mathrm{mm}$} & \multirow{2}{*}{ Total monsoonal rainfall $(\mathrm{mm})$} & \multirow{2}{*}{ Estimated monsoonal runoff $(\mathrm{mm})$} \\
\hline & June & July & August & September & & \\
\hline \multicolumn{7}{|c|}{ (1) Jharkhand Division } \\
\hline Bokaro & 178.5 & 318.8 & 286.0 & 256.9 & 1040.2 & 321.7 \\
\hline Hazaribagh & 180.4 & 327.8 & 297.6 & 234.7 & 1040.5 & 321.9 \\
\hline Jamtara & 216.8 & 347.6 & 339.9 & 278.2 & 1182.5 & 438.2 \\
\hline Dhanbad & 192.3 & 336.1 & 300.8 & 245.5 & 1074.7 & 349.9 \\
\hline \multicolumn{7}{|c|}{ (2) Gangetic West Bengal } \\
\hline Bankura & 206.9 & 312.1 & 311.5 & 230.0 & 1060.5 & 338.3 \\
\hline Burdwan & 229.4 & 324.8 & 303.6 & 240.3 & 1098.1 & 369.1 \\
\hline
\end{tabular}

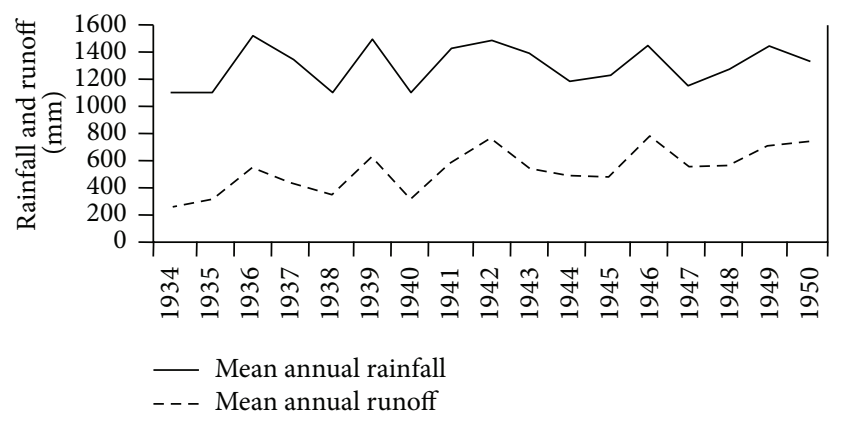

(a)

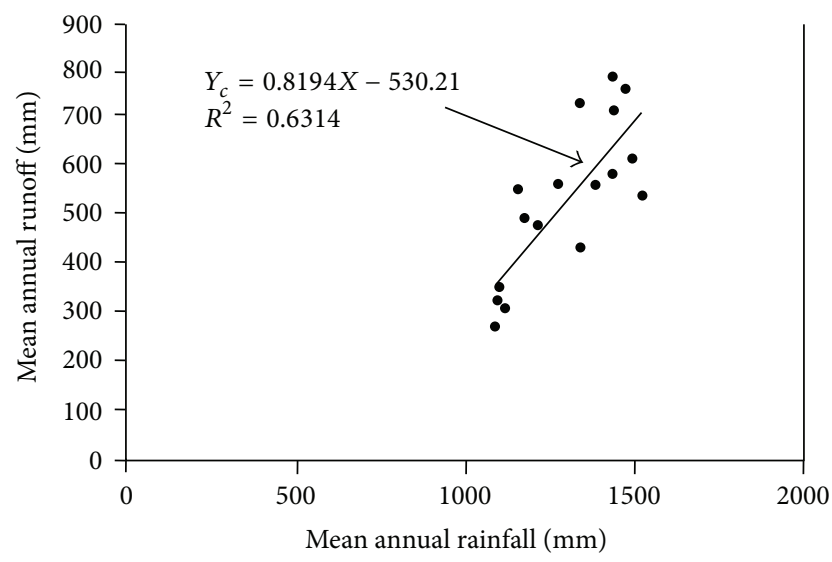

(b)

FIGURE 5: (a) Yearwise mean rainfall and runoff pattern at Rhondia from 1934 to 1950 and (b) increasing regression trend line between rainfall and runoff of Damodar Basin.

an average, estimated runoff is $548.89 \mathrm{~mm}$, having standard deviation of $153.67 \mathrm{~mm}$. From the trend of 1934-50, we have found that average annual runoff-rainfall ratio is $0.41(0.25$ to 0.54 ) which means that 41 percent of annual rainfall has possibility to convert into runoff in this area depending on different geographical conditions. It is a real fact that the largest part of runoff is generated at the time of peak monsoon (June to September) alone (when excess rainfall becomes direct runoff to the streams after fulfillment of surface storage). Therefore, using the districtwise normal monsoonal IMD rainfall data (1951-2003) of Bokaro, Dhanbad, Hazaribagh, Jamtara, Ramgarh, Bankura, and Burdwan, we have obtained the following status of runoff (Table 6).

On an average the normal monsoonal rainfall ranges from 1040.2 to $1182.5 \mathrm{~mm}$ per year and calculated runoff ranges from 321.7 to $438.2 \mathrm{~mm}$ per year. Both regions on an average yield have same runoff ( 357.9 to $353.7 \mathrm{~mm}$ ) in monsoon. It signifies that now both upper and lower portions of Damodar Basin yield the same runoff which has a cumulative effect as increasing runoff progresses towards Gangetic West Bengal. As funnel shape upper catchment carries 321.7-438.2 mm of runoff towards West Bengal and further narrow elongated alluvial lower basin adds 338.3 to $369.1 \mathrm{~mm}$ of runoff on the same season or months, therefore, in late August to September, when soil moisture and ground water recharges up to maximum level, the agglomerative effect of this runoff within the same period creates huge volume of stream flow or peak discharge in Maithon, Panchet Dams, and Durgapur Barrage.

According the Sen $[34,43]$, now DVC system is providing flood benefit of only $162.56 \mathrm{~mm}$ of surface runoff to the lower catchment, in place of $452.0 \mathrm{~mm}$ as advocated by $\mathrm{Mr}$. Voorduin [43]. But our result shows that, now, estimated mean monsoonal runoff (1951-2003) is $355.0 \mathrm{~mm}$, having $172.44 \mathrm{~mm}$ of unregulated runoff. This amount of runoff is not controlled by DVC storage system and is finally released by Durgapur Barrage into main River and canals. So there are ample chances of peak flood flow and inundation of Barddhaman Plains, when huge outflow of Durgapur Barrage will overtop its banks as the downstream cross-section of channel is reducing to a considerable extent from Barsul to Paikpara. In general, the annual runoff pattern of Damodar Basin is depicted as follows (Figure 6).

5.3. Predicting Potential Runoff in relation to Peak Discharge of Damodar. The channel flow or stream flow is the main form of surface water flow, and all the other surface and subsurface flow processes contribute to it. The precipitation which becomes stream flow may reach the stream by overland flow, subsurface flow, or both [3]. The observed or measured stream flow of Damodar River at Anderson Weir, Rhondia, is the flow collected from upper catchment area of Damodar River $\left(19,920 \mathrm{~km}^{2}\right)$ and appeared at an outlet of Weir. But that 


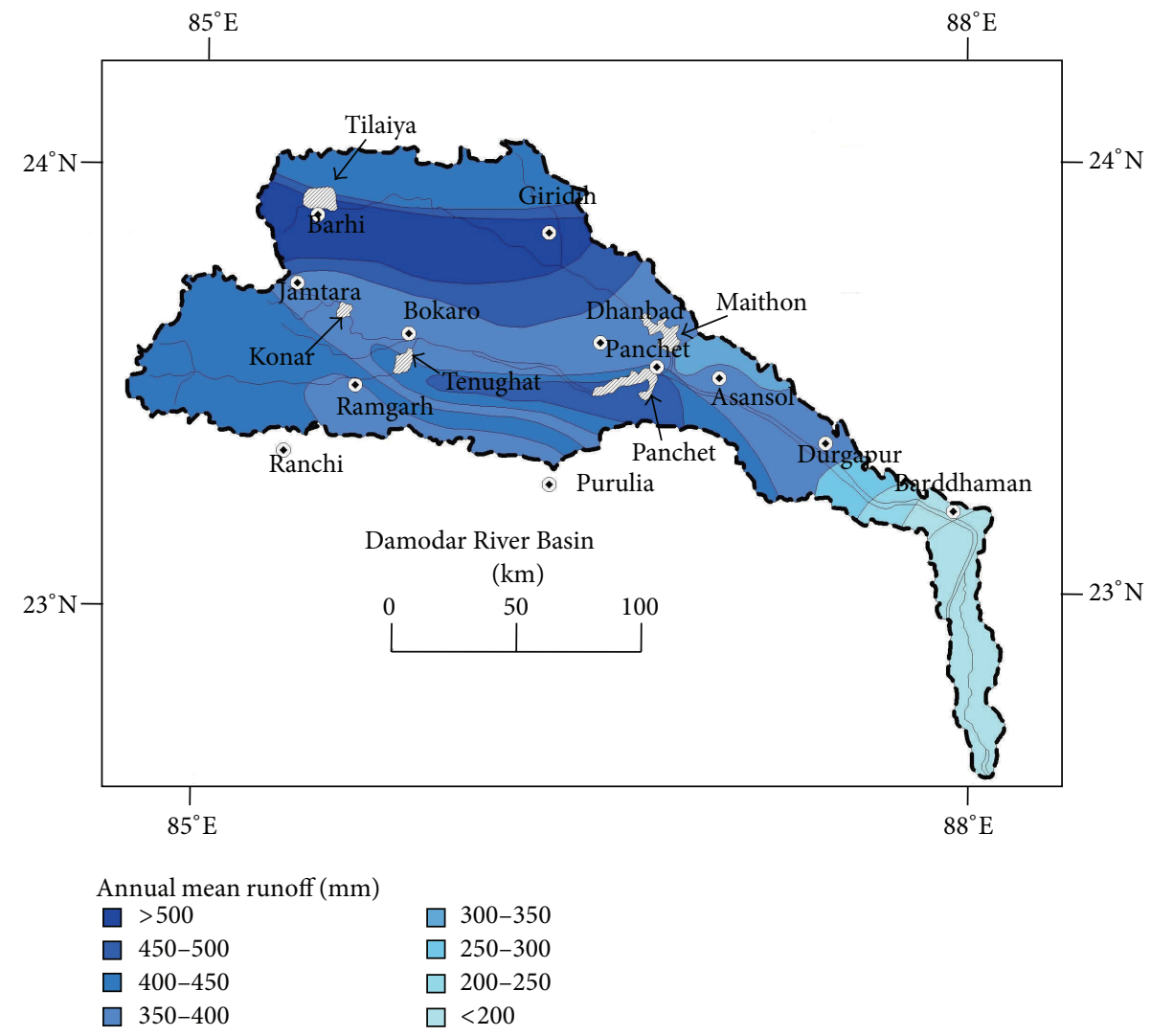

FIgURE 6: Average annual runoff pattern in the Damodar River Basin (2010).

measured flow does not reflect the actual stream flow because the reservoirs and dams store much water in them, though the measured stream flow can be regarded as uncontrolled inflow of upper catchment. It has been assumed that observed extreme level of steam flow rate of a day is the cumulative effect of total collective runoff of previous days in the upper catchment area of a river. Now, we have been attempting to estimate pre-dam (1933-1957) and post-dam (1958-2007) major contribution of runoff of upper catchment which is responsible for the peak stream flow at Rhondia.

Converting $\mathrm{m}^{3} \mathrm{~s}^{-1}$ (metric system unit of stream flow rate) into volume of flow $\left(\mathrm{m}^{3}\right)$ and dividing it by contributing catchment area (upper catchment of Damodar River, measured from Anderson Weir, Rhondia), we have been able to find the probable of potential depth of runoff responsible for that stream flow. The volume of water discharged in a period of 24 hours at a peak rate of $1 \mathrm{~m}^{3} \mathrm{~s}^{-1}$ is called "one $\mathrm{m}^{3} \mathrm{~s}^{-1}$ day" $\left(1 \mathrm{~m}^{3} \mathrm{~s}^{-1}\right.$ day $\left.=86,400 \mathrm{~m}^{3}=8.64 \mathrm{ha}-\mathrm{m}\right)$ [7].

We have categorized the calculation (Table 7 and Figure 7) into two important phases, (1) pre-dam period (1934-57) and (2) post-dam period (1958-2007), to understand runoff amount in past natural condition and present controlled condition. The calculated potential runoff depths of both periods reaffirm that, to reach the observed peak discharge level and volume of water passing through Anderson Weir, the upper catchment of Damodar River should collect the maximum amount of runoff water. In

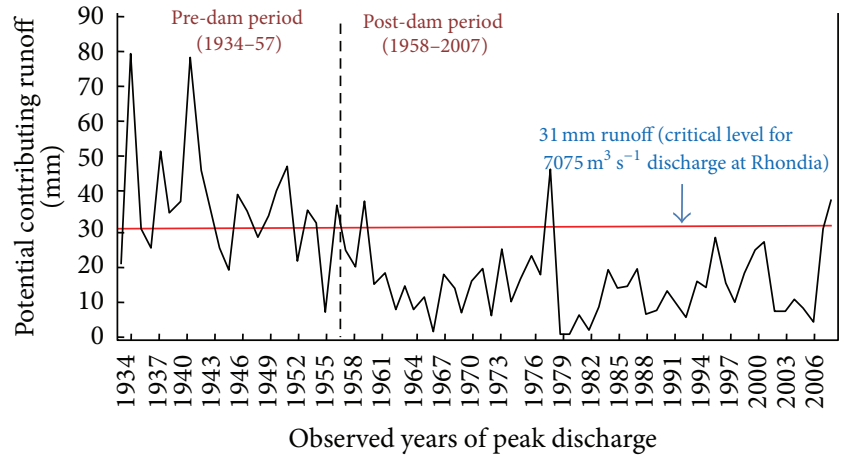

FIGURE 7: Pre-dam and post-dam change of potential contributing runoff in respect of peak discharge of Damodar River at Rhondia.

pre-dam period, when a single dam was constructed, the stream flow of Damodar River was much more extreme in all years, having mean peak discharge of $8378 \mathrm{~m}^{3} \mathrm{~s}^{-1}$. In that natural condition, the estimated runoff ranges from 20.78 to $78.56 \mathrm{~mm}$, but due to establishment of DVC Project, it is radically reduced and ranges from 1.79 to $47.36 \mathrm{~mm}$. Now, much of runoff water is stored behind the dams of upper catchment. In spite of low runoff supply and storage, lower Basin of Damodar (Barddhaman, Hooghly, and Howrah districts) is still facing annual flood. The estimated runoff of post-dam period is the unregulated outflow of DVC, though 
TABLE 7: Estimating potential runoff of upper catchment of Damodar River on the basis of selective annual peak discharges at Rhondia for pre-dam and post-dam period.

\begin{tabular}{|c|c|c|c|}
\hline Date of occurrence & $\begin{array}{c}{ }^{1} \text { Peak } \\
\text { discharge } \\
\text { in } \mathrm{m}^{3} \mathrm{~s}^{-1}\end{array}$ & $\begin{array}{l}\text { One- } \mathrm{m}^{3} \mathrm{~s}^{-1} \\
\text { day in } \mathrm{m}^{3}\end{array}$ & $\begin{array}{l}\text { Contributing } \\
\text { potential runoff } \\
\text { in } \mathrm{mm}\end{array}$ \\
\hline \multicolumn{4}{|l|}{$\begin{array}{l}\text { Pre-dam phase } \\
(1933-1957)\end{array}$} \\
\hline $12 / 7 / 1935$ & 18,112 & 1564876800 & 78.56 \\
\hline 6/9/1938 & 12,002 & 1036972800 & 52.05 \\
\hline 4/8/1939 & 7,989 & 690249600 & 34.65 \\
\hline $29 / 8 / 1940$ & 8,773 & 757987200 & 38.05 \\
\hline 10/10/1941 & 17,942 & 1550188800 & 77.82 \\
\hline $10 / 8 / 1942$ & 10,811 & 934070400 & 46.89 \\
\hline $5 / 8 / 1943$ & 8,384 & 724377600 & 36.36 \\
\hline $18 / 9 / 1946$ & 9,133 & 789091200 & 39.61 \\
\hline $18 / 8 / 1950$ & 9,561 & 826070400 & 41.47 \\
\hline $11 / 9 / 1951$ & 11,012 & 951436800 & 47.76 \\
\hline 26/9/1956 & 8,579 & 741225600 & 37.21 \\
\hline \multicolumn{4}{|l|}{$\begin{array}{l}\text { Post-dam phase } \\
(1958-2007)\end{array}$} \\
\hline $2 / 10 / 1959$ & 8,792 & 759628800 & 38.13 \\
\hline 3/10/1961 & 4,371 & 377654400 & 18.96 \\
\hline 19/9/1967 & 4,138 & 357523200 & 17.95 \\
\hline $17 / 7 / 1971$ & 4,556 & 393638400 & 19.76 \\
\hline $13 / 10 / 1973$ & 5,726 & 494726400 & 24.83 \\
\hline 19/9/1976 & 5,297 & 457660800 & 22.98 \\
\hline $27 / 9 / 1978$ & 10,919 & 943401600 & 47.36 \\
\hline $28 / 8 / 1980$ & 4,210 & 363744000 & 18.26 \\
\hline $14 / 9 / 1987$ & 4,567 & 394588800 & 19.80 \\
\hline 29/9/1995 & 6,522 & 563500800 & 28.28 \\
\hline 25/9/1999 & 5,690 & 491616000 & 24.68 \\
\hline $23 / 9 / 2000$ & 6,387 & 551836800 & 27.70 \\
\hline $24 / 9 / 2006$ & 7,035 & 607824000 & 30.51 \\
\hline $25 / 9 / 2007$ & 8,883 & 767491200 & 38.53 \\
\hline
\end{tabular}

the main portion of stream flow is coming from surface runoff. The above calculation can forecast the peak discharge or volume of flow at Rhondia if we can precisely estimate rainfall and runoff of upper catchment. When we look at the line graph of runoff (Figure 6), we have found that, after dam construction, the supply of runoff is decreased below $30 \mathrm{~mm}$ which is recommended as critical level for $7075 \mathrm{~m}^{3} \mathrm{~s}^{-1}$ peak discharge at Rhondia (threshold level of downstream flood, as recommended by DVC). But if we look at the trend of 1995-2007, we have found that after a sharp calm session, the contribution potential runoff amount is gradually increased. It signifies three facts: (1) declining storage capacity of reservoirs and unregulated outflow, (2) loss of carrying capacity of Damodar River to accommodate runoff, and (3) future risk of extreme flood at downstream section. We have mentioned the cumulative rainfall of past major flood events in relation to estimated runoff depth (Table 8). Here, the runoff coefficient to depict actual runoff of given days responsible for extreme peak discharge is estimated. Only 1 to 34 percent of rainfall is converted into runoff which appears as abnormal flood flow at Rhondia. So we can say that small amount of potential runoff appeared as gigantic flood flow due to wide areal coverage $\left(19,920 \mathrm{~km}^{2}\right)$ of upper catchment (fan shaped basin) to accommodate huge volume of water within two to three days of prolonged rainfall.

Now, we have employed Gumbel's distribution of extreme values to identify the standard project flood discharge and runoff of given return period (namely, 5, 10, 20, 50, 100, and 150 years flood) in Damodar Basin. In post-dam condition, 5 years return period of flood has possible peak discharge of $5,352 \mathrm{~m}^{3} \mathrm{~s}^{-1}\left(11,728 \mathrm{~m}^{3} \mathrm{~s}^{-1}\right.$ in pre-dam condition) and predicted runoff of $23.21 \mathrm{~mm}(50.87 \mathrm{~mm}$ in pre-dam condition). Again, 100 years of return period of standard flood has potential peak discharge of $12,670 \mathrm{~m}^{3} \mathrm{~s}^{-1}\left(10,919 \mathrm{~m}^{3} \mathrm{~s}^{-1}\right.$ in 1978) and predicted runoff of $54.95 \mathrm{~mm}(47.36 \mathrm{~mm}$ in 1978). When we observe the trend of peak discharge (19342007), we have found dominance $5000-7000 \mathrm{~m}^{3} \mathrm{~s}^{-1}$ of flood discharge in some years. So we should focus on 5,10 , and 20 years of flood to predict extreme flood discharge and contributing runoff (Table 9).

5.4. Declining Carrying Capacity of Channel and Chances of Floods. It is now considered that lower Damodar River has constantly lost its carrying capacity to store or accommodate flood water within its confined valley in the time of peak monsoon [47, 57]. To verify it, we have calculated the potential volume water of a particular reach which may be accommodated limiting its carrying capacity. To estimate the maximum bankfull capacity to carry flood flow and threshold level of flood discharge, we have subdivided the river from Anderson Weir to downstream into three reaches, namely, (1) Rhondia to Jujuti reach, (2) Jujuti to Chanchai reach, and (3) Chanchai to Paikpara reach (Table 10). Using SRTM elevation data, we have drawn six to eight cross profiles of three reaches across Damodar River, taking an equal interval and mean cross-sectional area, mean depth, mean length of each reach, and mean bankfull volume of each reach are calculated using those profiles. It was estimated by Voodruin and DVC that if all the proposed dams were established, we could moderate the peak discharge up to $7075 \mathrm{~m}^{3} \mathrm{~s}^{-1}$ $\left(611,280,000 \mathrm{~m}^{3} \mathrm{~s}^{-1} /\right.$ day $)$ at Rhondia and any discharge above it would cause flood at downstream section [58, 59]. But, unfortunately, total DVC project is not completed till date and, after spending sixty years (from establishment of DVC), the dams, barrages, and river itself are much more silted due to engineering obstructions, annual regulation of stream flow, and embankments. So it is clear that, now, the threshold level is much less than $7075 \mathrm{~m}^{3} \mathrm{~s}^{-1}$, but question is how much it is decreased. For that reason, we have estimated the present threshold level of peak discharge to predict the overflow condition and flood risk of lower Damodar River (Table 10).

As the mean cross-sectional area of river is decreased downstream $\left(12,290\right.$ to $\left.7077 \mathrm{~m}^{2}\right)$, the bankfull volume of 
TABLE 8: Relating rainfall, peak discharge, and estimated runoff of Damodar Basin in selected major flood events.

\begin{tabular}{|c|c|c|c|c|c|}
\hline $\begin{array}{l}\text { Consecutive date of } \\
\text { rainfall }\end{array}$ & $\begin{array}{l}\text { Cumulative average } \\
\text { rainfall in } \mathrm{mm}\end{array}$ & $\begin{array}{c}\text { Date of peak } \\
\text { discharge }\end{array}$ & $\begin{array}{l}\text { Magnitude of } \\
\text { peak discharge } \\
\text { in } \mathrm{m}^{3} \mathrm{~s}^{-1}\end{array}$ & $\begin{array}{l}\text { Estimated } \\
\text { runoff in mm }\end{array}$ & $\begin{array}{c}\text { Runoff } \\
\text { coefficient }\end{array}$ \\
\hline August 5-8, 1913 & 234 & 8/8/1913 & 18,406 & 79.83 & 0.34 \\
\hline August 10-12, 1935 & 196 & $12 / 8 / 1935$ & 18,112 & 78.56 & 0.40 \\
\hline September 14-16, 1958 & 168 & $16 / 9 / 1958$ & 4,682 & 20.30 & 0.12 \\
\hline $\begin{array}{l}\text { September 30-Oct 2, } \\
1959\end{array}$ & 152 & 2/11/1959 & 8,792 & 38.13 & 0.25 \\
\hline September 26-27, 1978 & 160 & $27 / 9 / 1978$ & 10,919 & 47.36 & 0.29 \\
\hline $\begin{array}{l}\text { September 18-21, } \\
2000\end{array}$ & 359 & $23 / 9 / 2000$ & 6,387 & 27.70 & 0.08 \\
\hline
\end{tabular}

Data Source: [21].

TABLE 9: Pre-dam and post-dam comparison of standard peak flood discharge and estimated runoff of variable return period using Gumbel distribution.



Note: $K_{T}$ : frequency factor of Gumbel distribution, Q: estimated or projected peak discharge, $y_{\text {mean }}$ : mean of peak discharges, $\sigma_{n}$ : standard deviation of distribution, and $n$ : number of variables.

TABLE 10: Estimation of present threshold level of flood discharge in lower Damodar River.

\begin{tabular}{lccccc}
\hline $\begin{array}{l}\text { Reaches of } \\
\text { Damodar }\end{array}$ & $\begin{array}{c}\text { Mean } \\
\text { cross-sectional } \\
\text { area }\left(\mathrm{m}^{2}\right)\end{array}$ & $\begin{array}{c}\text { Range of } \\
\text { channel depth } \\
(\mathrm{m})\end{array}$ & $\begin{array}{c}\text { Bankfull volume } \\
\left(\mathrm{m}^{3}\right) \text { of total reach } \\
\left(\mathrm{m}^{3} \mathrm{~s}^{-1} / \text { day }\right)\end{array}$ & $\begin{array}{c}\text { Present estimated } \\
\text { level of discharge } \\
\left(\mathrm{m}^{3} \mathrm{~s}^{-1}\right)(\text { threshold } \\
\text { level })\end{array}$ & $\begin{array}{c}\text { Discharge }\left(\mathrm{m}^{3} \mathrm{~s}^{-1}\right) \\
\text { as recommended } \\
\text { earlier by D.V.C. }\end{array}$ \\
$\begin{array}{l}\text { (1) Rhondia to } \\
\text { Jujuti }\end{array}$ & 12,290 & $3.89-7.84$ & 346568177 & 4011 & $\begin{array}{c}\text { Excess } \\
\text { uncontrolled } \\
\text { discharge }\left(\mathrm{m}^{3} \mathrm{~s}^{-1}\right)\end{array}$ \\
$\begin{array}{l}\text { (2) Jujuti to } \\
\text { Chanchai }\end{array}$ & 7082 & $5.08-6.85$ & 204380800 & 2366 & 7075 \\
$\begin{array}{l}\text { (3) Chanchai to } \\
\text { Paikpara }\end{array}$ & 7077 & $4.47-9.75$ & 133259910 & 1542 & 4709 \\
\hline
\end{tabular}

reach also is declined (346568177 to $\left.133259910 \mathrm{~m}^{3}\right)$. It is estimated that Damodar River has lost its former carrying capacity (up to $611280000 \mathrm{~m}^{3}$ for the discharge of $7075 \mathrm{~m}^{3} \mathrm{~s}^{-1}$ ), having a loss of 264711823 to $478020090 \mathrm{~m}^{3}$ in one $\mathrm{m}^{3} \mathrm{~s}^{-1}$ /day. Now, we have estimated that threshold levels of peak discharge are 4011, 2366, and $1542 \mathrm{~m}^{3} \mathrm{~s}^{-1}$, respectively, for the selected reaches of lower Damodar River (Rhondia to Paikpara). So, now, any bankfull discharge above $4011 \mathrm{~m}^{3} \mathrm{~s}^{-1}$ at Rhondia is considered to be flood discharge for lower catchment. That is why, in post-dam period, Barddhaman, Hooghly, and Howrah Districts had experienced high magnitude of floods in 1958, 1961, 1976, 1978, 1995, 1999, 1987, 2000, 2006, 2007, 2009, and 2013. The line graph also denotes that, from 1995, frequently the peak discharge have crossed the threshold limit and its magnitude is rising after the devastating floods of 1978 and 2000 (Figure 8).

With increasing distance from the Anderson Weir, Rhondia, the channel dimensions of channel cross-sectional area $\left(A_{b}\right)$, volume of that cross-section $\left(V_{c}\right)$, bankfull width $\left(W_{b}\right)$, maximum depth (thalweg depth) of that profile $\left(D_{\max }\right)$, and width-depth ratio $(W / D)$ are gradually decreased with low competence of accommodating peak discharge (Figure 9). The estimated maximum and minimum bankfull discharges are $5848 \mathrm{~m}^{3} \mathrm{~s}^{-1}$ and $529 \mathrm{~m}^{3} \mathrm{~s}^{-1}$, respectively, with the crosssectional channel area of $6360 \mathrm{~m}^{2}$ and $812 \mathrm{~m}^{2}$ being at those sections. The $W / D$ is significantly decreased at downstream from 206.59 to 12.08 , reflecting the narrowness of channel but maximum channel depth $\left(D_{\max }\right)$ is increased from 




Figure 8: Post-dam trend of peak discharge at Rhondia above estimated threshold level of discharge (note: cumec: $\mathrm{m}^{3} \mathrm{~s}^{-1}$ ).

8.83 to 21.53 metres. The average monsoonal discharge is estimated to be near about $6071 \mathrm{~m}^{3} \mathrm{~s}^{-1}$ up to Bardhhaman town and $2781 \mathrm{~m}^{3} \mathrm{~s}^{-1}$ up to Paikpara. The annual peak flow is projected approximately $10,213 \mathrm{~m}^{3} \mathrm{~s}^{-1}$ and $12,393 \mathrm{~m}^{3} \mathrm{~s}^{-1}$ in between Ramgopalpur and Gohagram. This is reduced up to $2106-3048 \mathrm{~m}^{3} \mathrm{~s}^{-1}$ in between Jamalpur and Paikpara. This information again reconfirms the risk of overflow at the time of peak monsoon discharge in the lower segment of Damodar River.

\section{Conclusion}

Damodar River of India, its history of flood discharges, wide coverage of monsoonal rainfall, excessive volume of runoff, declining carrying capacity of River, and increasing human actions on its active domain are effectively explained here from a hydrogeomorphic perspective to analyze its dynamic fluvial phenomena in relation to flood climate and risk assessment. This study extracts significant information regarding past, present, and future trend of flood discharge and continuous river's responses to rainfall, runoff, and flood control system of DVC. Employing Gumbel's distribution of extreme annual discharge values, we have found that 100 years of flood discharge will reach up to $11,322 \mathrm{~m}^{3} \mathrm{~s}^{-1}$ in post-dam period, but the flood of that magnitude is associated with 5 years of recurrence interval in pre-dam period. It suggests that DVC flood regulation system manages to increase the recurrence interval of peak annual discharge up to 50 percent. In every 14 years, there will be 7.15 percent probability of occurrence to reach peak discharge up to $7075 \mathrm{~m}^{3} \mathrm{~s}^{-1}$. This discharge is contributed by increasing monsoonal runoff of upper catchment of Damodar which ranges from 320 to $440 \mathrm{~mm}$ per year and, in post-dam period, there is requirement of only $30 \mathrm{~mm}$ runoff to reach peak discharge of $7035 \mathrm{~m}^{3} \mathrm{~s}^{-1}$ at Rhondia. But, now, we have estimated that only $4011 \mathrm{~m}^{3} \mathrm{~s}^{-1}$ of discharge (return period of 3 years) is considered as threshold limit of flood discharge at Rhondia and, when we go downstream section, it is reduced up to only $1542 \mathrm{~m}^{3} \mathrm{~s}^{-1}$. For that reason, lower Damodar River has annually experienced overflow condition and adjoining parts of Barddhaman, Hooghly, and Howrah are flooded in peak monsoon. Now, it is said that present carrying capacity of

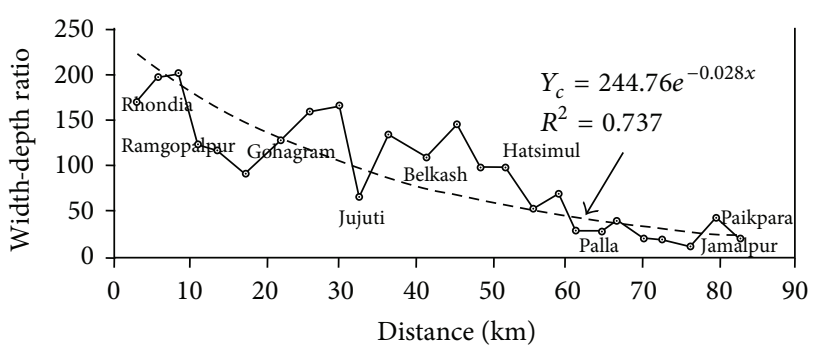

(a)

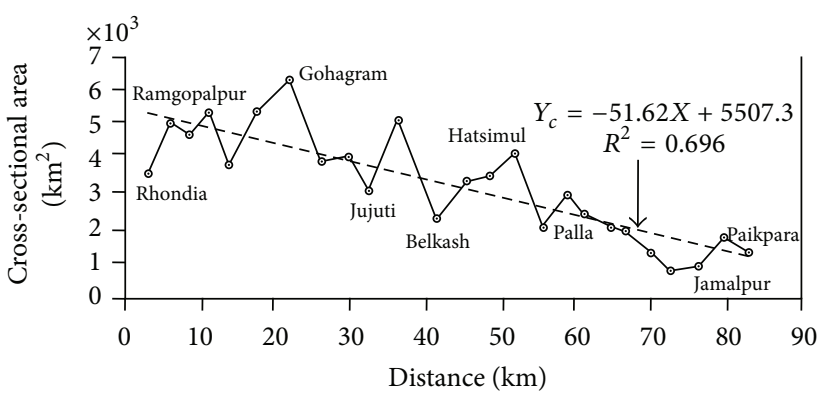

(b)

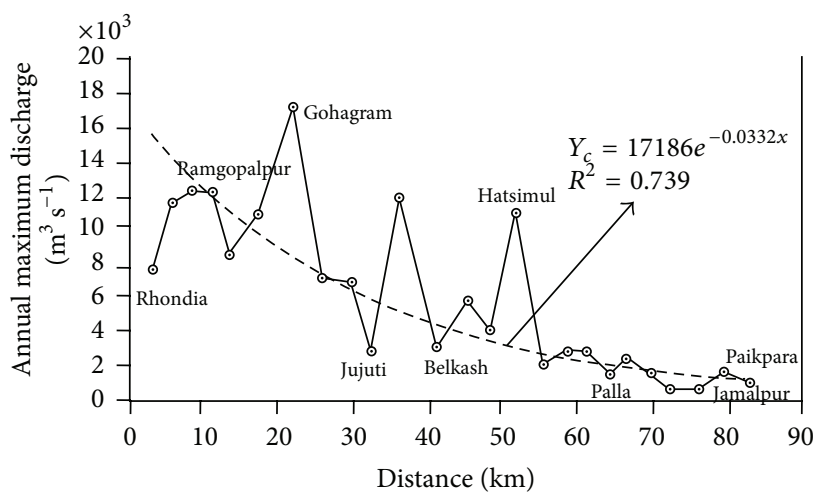

(c)

FIgURE 9: Downstream site-specific hydrogeomorphic changes of Damodar River, with increasing downstream distance from Rhondia: (a) $W_{b} / D_{\max }$ is decreased, (b) $A_{b}$ is decreased, (c) level of $Q_{\max }$ is significantly decreased, signifying high flood risk.

lower Damodar is reduced to $1415 \mathrm{~m}^{3} \mathrm{~s}^{-1}$ only. Remembering the emerging problems of riverine flood, we have mentioned that the current factors of flood risk of lower Damodar River are as follows: (1) bottle-neck and physically handicapped location of lower Damodar Basin in the Gangetic West Bengal (huge volume of channel flow collected from funnel-shaped rocky upper catchment passing through narrow and shallow reach of lower Damodar) including the tidal effect of lower reach, (2) three to four days continuous heavy rainfall due to SW-NE directional monsoonal depressions, (3) uncontrolled runoff of upper catchment, (4) increasing siltation of dams, barrages, canals, and river beds, (5) only four large dams (i.e., Tilaiya, Konar, Maithon, and Panchet), Tenughat Reservoir, and Durgapur Barrage serving the purpose of all proposed eight large dams and combined flood moderation capacity of Maithon and Panchet dams reducing up to only 32 per cent, (6) the dams compelling to release excess water in the month 
of late September because of already storing water in the previous months of monsoon, (7) annual peak discharge of short duration occurring in between late September and October at the time of over-saturation of alluvial soils, ground water and existing streams, and (8) drainage congestion and encroachment of active river bed and floodplain.

From the perspective of flood climate, the recurrent floods of Damodar River is directly influenced by rainstorms of 3- to 4-day duration, path of cyclone, extreme rainfall event of 3 to 6 hours, runoff yield, and discharging of excess water from the upstream dams and Durgapur barrage. From the standpoint of flood hydrology, the stream flow during high magnitude floods in our study area is primarily confined within bankfull level, with occasional overtopping of the levees. The floodplain flow, whenever it took place, is intermittent in nature. To manage floods, we should focus on the travel time of flood waves from Durgapur barrage to the downstream end and on the up-to-date accurate estimation of critical bankfull discharge at the ungauged sites of lower Damodar River.

At last, it can be said that human and technology solely cannot control the river dynamics in our favour but we can adopt or adjust ourselves to the dynamicity of river discharges through a complete understanding of hydrogeomorphic behaviours of an active alluvial river, like Damodar. From the above analysis, it is understood that observing the drawbacks of large scale Damodar Valley Planning, we can only predict or manage the flood discharge to a certain level, not stopping it completely. So scrutinizing the exiting framework of basin planning, it is the exact time to rethink the increasing flood risk of lower Damodar River and renovation of Damodar Valley Planning in West Bengal in the frame of global warming and climate change.

\section{Conflict of Interests}

The authors declare that there is no conflict of interests regarding the publication of this paper.

\section{Acknowledgments}

The authors sincerely thank Achim A. Beylich (Editor) for giving them suggestions to enrich the work in a scientific way. They are very much thankful to the reviewers for providing valuable comments and suggestions on the paper. This study was supported by the Department of Geography, The University of Burdwan (West Bengal, India).

\section{References}

[1] M. Allaby, Floods, Viva Books Private Limited, New Delhi, India, 2006.

[2] H. M. Raghunath, Hydrology_Principles, Analysis and Design, New Age International Publishers, New Delhi, India, 2011.

[3] V. T. Chow, D. R. Maidment, and L. M. Mays, Applied Hydrology, McGraw Hill Book, New York, NY, USA, 1988.

[4] S. S. Sharma, "Floods in West Bengal-nature, analysis and solution," in Changing Environmental Scenario, S. Basu, Ed., pp. 315-322, acb Publication, Kolkata, India, 2002.
[5] B. P. Hayden, "Flood climate," in Flood Geomorphology, V. R. Baker, R. C. Kochel, and P. C. Patton, Eds., pp. 13-27, John Wiley \& Sons, New York, NY, USA, 1988.

[6] K. K. Hirschboeck, "Flood hydroclimatology," in Flood Geomorpholog, V. R. Baker, R. C. Kochel, and P. C. Patton, Eds., pp. 2750, John Wiley \& Sons, New York, NY, USA, 1988.

[7] P. J. R. Reddy, A Textbook of Hydrology, University Science Press, Bangalore, India, 2011.

[8] S. Nandargi and O. N. Dhar, "High frequency floods and their magnitudes in the Indian rivers," Journal of the Geological Society of India, vol. 61, no. 1, pp. 90-96, 2003.

[9] K. Parthasarathy, "Weather in relation to floods in Bihar, Bengal and Assam during July and August 1954," Journal of Scientific and Industrial Research, vol. 14, no. A, pp. 115-119, 1954.

[10] U. K. Bose, "Preliminary meteorological study associated with West Bengal rivers," Indian Journal of Power and River Valley Development, vol. 7, no. 9, pp. 23-24, 1957.

[11] P. Singh, A. S. Ramanathan, and V. G. Ghanekar, "Flash floods in India," pp. 114-118, 1974, http://ks360352.kimsufi.com/redbooks/a112/iahs_112_0114.pdf.

[12] V. S. Kale, "Geomorphic effects of monsoon floods on Indian rivers," Natural Hazards, vol. 28, no. 1, pp. 65-84, 2003.

[13] V. S. Kale, "Fluvial hydrology and geomorphology of monsoondominated Indian rivers," Revista Brasileira de Geomorfologia, vol. 6, no. 1, pp. 63-73, 2005.

[14] V. S. Kale, "Research on floods in India," 2009, http://scholar .google.co.in/citations?view_op=view_citation\&hl=en\&user= eyv0fA8AAAAJ\&cstart=60\&citft=1\&citft=2\&email_for $\_o p=s a-$ ndipanghosh19\%40gmail.com\&citation_for_view=eyv0fA8AAAAJ:M3NEmzRMIkIC.

[15] O. N. Dhar and S. Nandargi, "Hydrometeorological aspects of floods in India," Natural Hazards, vol. 28, no. 1, pp. 1-33, 2003.

[16] A. K. Singhvi and V. S. Kale, "Paleoclimate studies in India: last Ice Age to the Present," GBP-WCRP-SCOPE-Report series 4, Indian National Science Academy, 2009.

[17] P. Guhathakurta, O. P. Sreejith, and P. A. Menon, "Impact of climate change on extreme rainfall events and flood risk in India," Journal of Earth System Science, vol. 120, no. 3, pp. 359373, 2011.

[18] C. Ramaswamy, "Meteorological aspects of severe floods in India, 1923-1979," Meteorological Monograph Hydrology no. 10, Indian Meteorological Department, 1987.

[19] World Bank, "Climate change impacts in droughts and floods affected areas: case studies in India," Report No. 43946-IN, Development of the World Bank, 2008.

[20] M. K. Saha, "River flood forecasting and preparedness-Lower Damodar Valley in West Bengal," in River Floods-A SocioTechnical Approach, K. M. B. Rahim, N. Mukhopadhyay, and D. Sarkar, Eds., pp. 244-249, ACB Publications, Kolkata, India, 2005.

[21] K. Bhattacharyya, The Lower Damodar River, India-Understanding the Human Role in Changing Fluvial Environment, Springer, New York, NY, USA, 2011.

[22] G. Nagle, River and Water Management, Hodder and Stoughton, London, UK, 2003.

[23] R. J. Garde and U. C. Kothyari, "Flood estimation in Indian catchments," Journal of Hydrology, vol. 113, no. 1-4, pp. 135-146, 1990.

[24] V. S. Kale, S. Mishra, Y. Enzel, L. L. Ely, S. N. Rajaguru, and V. R. Baker, "Flood geomorphology of the Indian peninsular rivers," Journal of Applied Hydrology, vol. 6, no. 1-4, pp. 40-55, 1995. 
[25] S. N. Rajaguru, A. Gupta, V. S. Kale et al., "Channel form and processes of the flood-dominated Narmada River, India," Earth Surface Processes and Landforms, vol. 20, no. 5, pp. 407-421, 1995.

[26] V. S. Kale, "Monsoon floods in India: a hydro-geomorphic perspective," in Flood Studies in India, V. S. Kale, Ed., pp. 229256, Geological Society of India, Bengaluru, India, 1998.

[27] V. S. Kale, "Long-period fluctuations in monsoon floods in the Deccan Peninsula, India," Journal of the Geological Society of India, vol. 53, no. 1, pp. 5-15, 1999.

[28] D. C. Goswami, "Fluvial regime and flood hydrology of the Brahmaputra River, Assam," in Flood Studies in India, V. S. Kale, Ed., pp. 53-76, Geological Society of India, Bangalore, India, 1998.

[29] P. R. Rakhecha, "Highest floods in India," in Proceedings of the Symposium on the Extreme of the Extremes: Extraordinary Floods, pp. 167-172, IAHS Publication, no. 271, Reykjvik, Icleand, 2002.

[30] R. Jha and V. Smakthin, "Review of methods of hydrological estimation at ungauged sites in India," International Water Management Institute Working Paper 130, 2008.

[31] S. Mukhopadhyay, "A geo-environmental assessment of flood dynamics in lower Ajoy River inducing sand splay problem in eastern India," Ethiopian Journal of Environmental Studies and Management, vol. 3, no. 2, pp. 96-110, 2010.

[32] V. C. Jha and H. Bairagya, "Floodplain planning based on statistical analysis of Tilpara Barrage discharge: a case study on Mayurakshi River Basin," Caminhos de Geografia, vol. 13, no. 43, pp. 326-346, 2012.

[33] E. L. Glass, "Floods of the Damodar River and rainstorms producing them," Minutes of the Proceedings, vol. 217, pp. 333346, 1924.

[34] P. K. Sen, "The genesis of floods in the lower Damodar catchment," in The Concepts and Methods in Geography, P. K. Sen, Ed., pp. 71-85, University of Burdwan, Bardhaman, India, 1985.

[35] M. R. Goodall, "River valley planning in India: the Damodar," The Journal of Land and Public Utility Economics, vol. 21, no. 4, pp. 371-375, 1945.

[36] W. Krik, “The Damodar valley—valley opima," Geographical Review, vol. 40, no. 3, pp. 415-443, 1950.

[37] S. K. Pramanik and K. N. Rao, Hydrometeorology of the Damodar Catchment, 2012, http://iahs.info/redebooks/a036/ 036060.

[38] K. Bagchi, "The Damodar Valley development and its impact on the region," in Indian Urbanization and Planning: Vehicle of Modernization, G. N. Allen and A. K. Dutt, Eds., pp. 232-241, Tata McGraw-Hill, New Delhi, India, 1977.

[39] D. Roy, S. Mukherjee, and B. Bose, "Regulation of a multipurpose reservoir system: Damodar Valley, India," in Proceedings on Man's Influences on Freshwater Ecosystems and Water Use, IAHS Publication no. 230, pp. 95-99, 1995.

[40] D. K. Mishra, "Living with floods: people's perspective," Economic and Political Weekly, vol. 36, no. 2, pp. 2756-2761, 2001.

[41] S. Sengupta, "River and floods," Breakthrough, vol. 9, no. 2, pp. 2-8, 2001.

[42] S. Chandra, India Flood Management-Damodar River Basin, 2012, http://www.apfm.info/publications/casestudies/cs_india full.

[43] P. K. Sen, "Flood hazards and river bank erosion in the Lower Damodar Basin," in Indian Geomorphology, H. S. Sharma, Ed., pp. 95-108, Concept Publishing Company, New Delhi, India, 1991.
[44] M. Majumder, P. Roy, and A. Mazumdar, "An introduction and current trends of Damodar and Rupnarayan River Network," in Impact of Climate Change on Natural Resource Management, B. K. Jana and M. Majumder, Eds., pp. 461-480, Springer, New York, NY, USA, 2010.

[45] S. P. Chatterjee, Damodar Planning Atlas, NATMO, Calcutta, India, 1969.

[46] F. G. Bell, Geological Hazards: Their Assessment, Avoidance and Mitigation, E. \& F.N. Spon, London, UK, 1999.

[47] K. Rudra, "Floods in West Bengal, 2000—causes and consequences," in Changing Environmental Scenario, S. Basu, Ed., pp. 326-347, ACB Publications, Kolkata, India, 2002.

[48] R. D. Dhir, P. R. Ahuja, and K. G. Majumdar, "A study on the success of reservoir based on the actual and estimated runoff," Research Session of Central Board of Irrigation and Power, vol. 68, 1958.

[49] E. J. Gumbel, "The return period of flood flows," The Annals of Mathematical Statistics, vol. 12, no. 2, pp. 163-190, 1941.

[50] H. R. Betal, "Identification of slope categories in Damodar Valley, India," in Selected Papers on Physical Geography, S. P. Chatterjee and S. P. Dasgupta, Eds., vol. 1, pp. 4-6, National Committee for Geography, Calcutta, India, 1970.

[51] G. N. Rao, "Occurrence of heavy rainfall around the confluence line in monsoon disturbances and its importance in causing floods," Journal of Earth System Science, vol. 110, no. 1, pp. 8794, 2001.

[52] M. K. Goyal and C. S. P. Ojha, "Analysis of mean monthly rainfall runoff data of Indian Catchments using dimensionless variables by neutral networks," Journal Environment Protection, vol. 1, pp. 135-146, 2010.

[53] M. Lal, T. Nozawa, S. Emori et al., "Future climate change: implications for Indian summer monsoon and its variability," Current Science, vol. 81, no. 9, pp. 1196-1207, 2001.

[54] C. O. Wisler and E. F. Brater, Hydrology, John Wiley \& Sons, New York, NY, USA, 1959.

[55] D. W. Reed, “Reinforcing flood-risk estimation," Philosophical Transactions: Mathematical, Physical and Engineering Sciences, vol. 360, no. 1796, pp. 1371-1387, 2002.

[56] R. J. More, “The basin hydrological cycle," in Water, Man and Earth, R. J. Chorley, Ed., pp. 67-75, Methuen and Co., London, UK, 1969.

[57] P. K. Roy and A. Mazumder, "Hydrological impacts of climatic variability on water resources o the Damodar River Basin, India," in Regional Hydrological Impacts of Climate Change: Impact, Assessment and Decision Making, T. Wagener, S. Franks, H. V. Gupta et al., Eds., pp. 147-156, IAHS Publication, London, UK, 2005.

[58] S. C. Mukhopadhyay, "Comtemporary issues in geography with particular emphasis on the flood hazards of West Bengal," in Contemporary Issues and Techniques in Geography, R. Basu and S. Bhaduri, Eds., pp. 77-110, Progressive Publishers, Kolkata, India, 2007.

[59] S. Ghosh, Flood Hydrology and Risk Assessment_Flood Study in a Dam-Controlled River of India, Lambert Academic Publishing, Saarbrücken, Germany, 2013. 

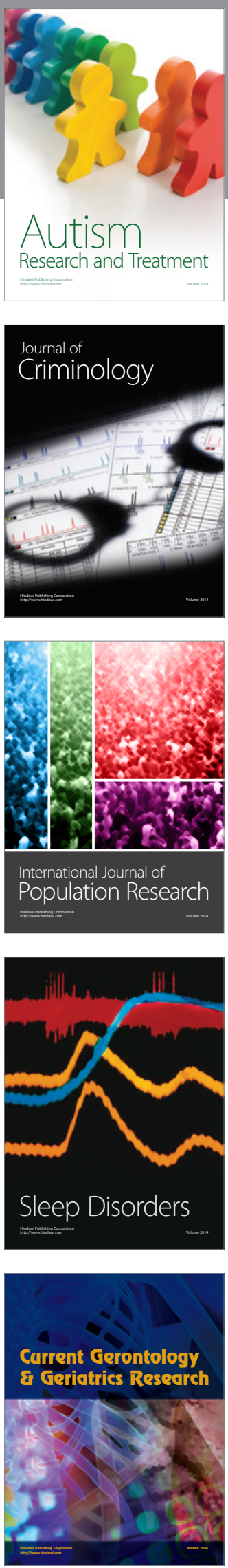
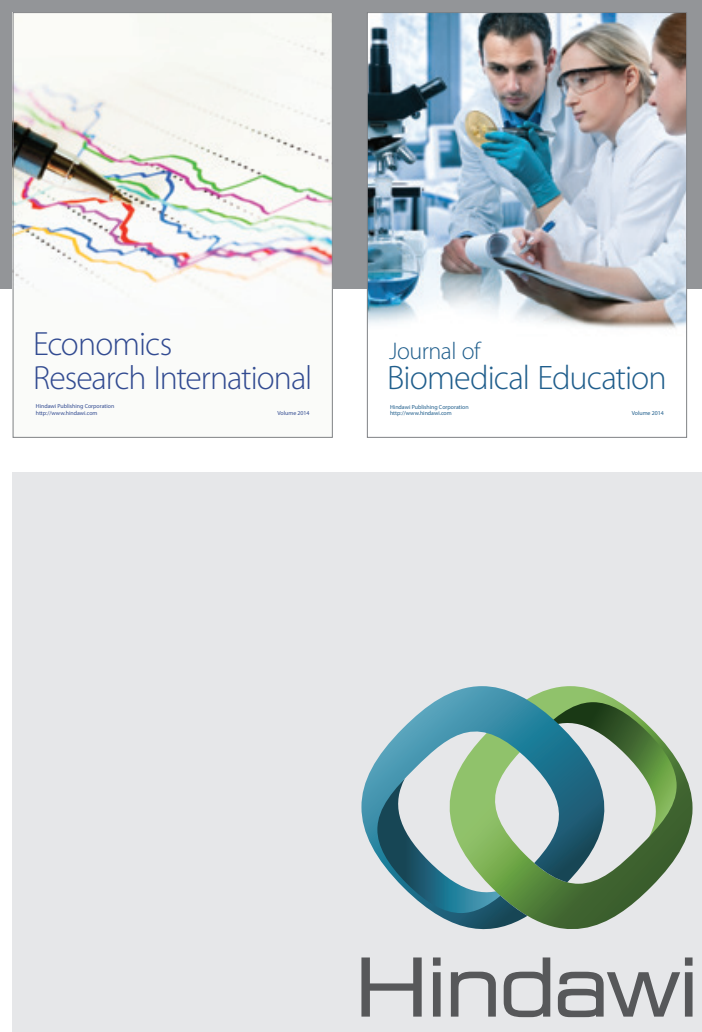

Submit your manuscripts at

http://www.hindawi.com
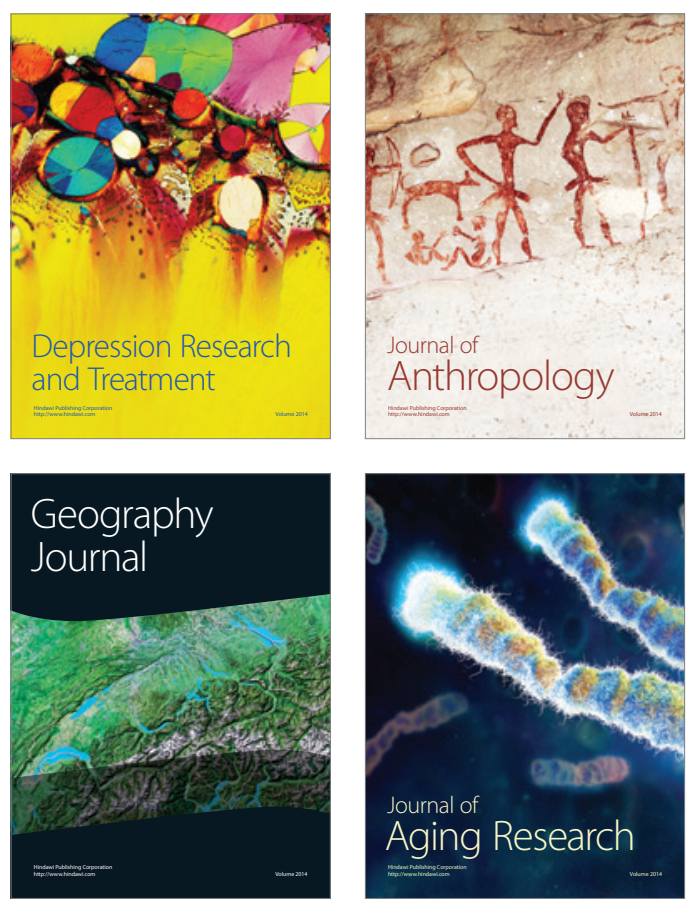


(D)
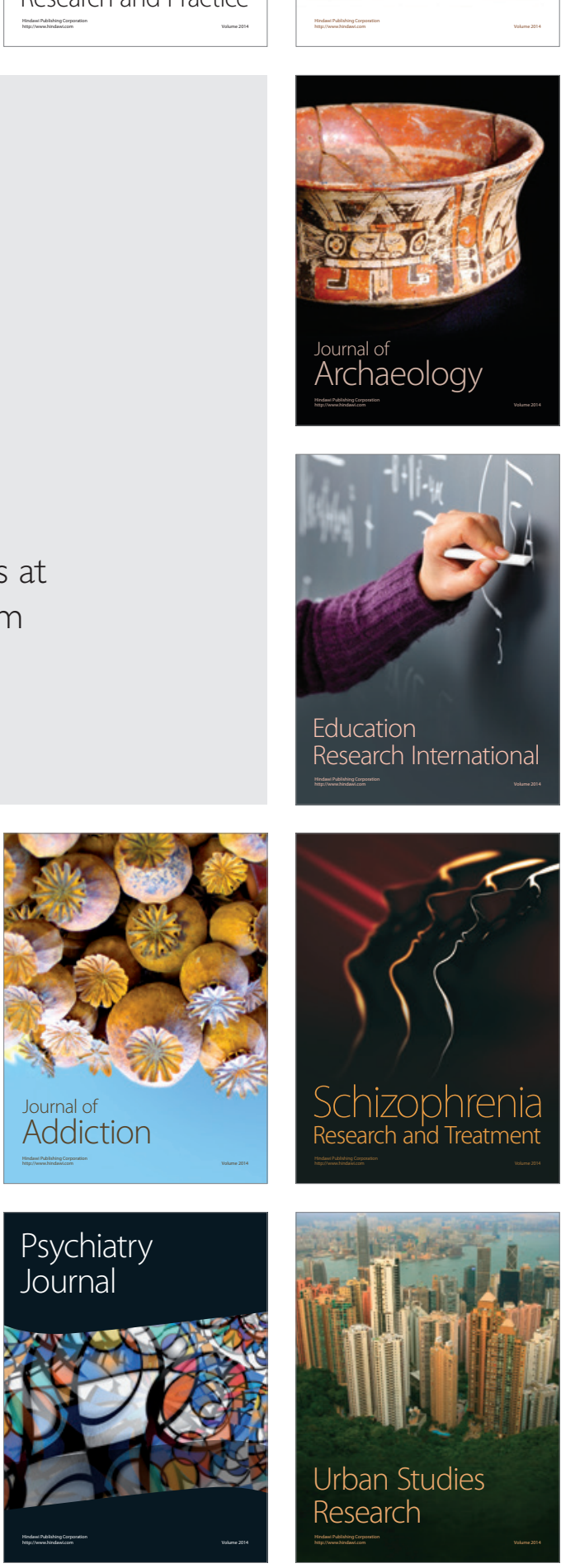